Supporting Information for:

\title{
Spectroscopic and Computational Evidence that [FeFe] Hydrogenases Operate Exclusively with CO- bridged Intermediates
}

\author{
James A. Birrell, ${ }^{\dagger} \pi^{*}$ Vladimir Pelmenschikov, ${ }^{\S}$ Nakul Mishra,${ }^{\ddagger}$ Hongxin Wang, ${ }^{\star}$ \\ Yoshitaka Yoda," Kenji Tamasaku," Thomas B. Rauchfuss, ${ }^{\#}$ Stephen P. Cramer, ${ }^{\perp}$ \\ Wolfgang Lubitz, ${ }^{\dagger}$ and Serena DeBeer ${ }^{\dagger}$
}

${ }^{\dagger}$ Max Planck Institute for Chemical Energy Conversion, Stiftstrasse 34-36, 45470 Mülheim an der Ruhr, Germany

${ }^{\S}$ Institut für Chemie, Technische Universität Berlin, Strasse des 17 Juni 135, 10623 Berlin,

Germany

Department of Chemistry, University of California, Davis, One Shields Avenue, Davis, California 95616, United States

"JASRI SPring-8, 1-1-1 Kouto, Mikazuki-cho, Sayo-gun, Hyogo 679-5198, Japan

\#School of Chemical Sciences, University of Illinois, 600 S. Mathews Avenue, Urbana, Illinois

61801, United States

${ }^{\perp}$ SETI Institute, Mountain View, California 94043, United States

*Author to whom correspondence should be addressed:

Max Planck Institute for Chemical Energy Conversion, Stiftstraße 34-36, D-45470 Mülheim an der Ruhr, Germany.

Tel: +49 (0)208 306 - 3845, E-mail: james.birrell@ cec.mpg.de

IThese authors contributed equally to this work. 


\section{Table of Contents:}

\section{Supplementary Figures}

Figure S1 | Temperature dependent FTIR of $C r \mathrm{HydA} 1$ in the $\mathrm{H}_{\text {sred }} \mathrm{H}^{+}$state in $\mathrm{H}_{2} \mathrm{O}$

Figure S2 | Temperature dependent FTIR of CrHydA1 in the $\mathrm{H}_{\text {sred }} \mathrm{H}^{+}$state in $\mathrm{H}_{2} \mathrm{O}$ before spline curve fitting for background subtraction

Figure S3 | Close up of the $\mathrm{H}_{\text {hyd }}$ bridging $\mathrm{CO}$ region in the temperature dependent FTIR of $\mathrm{CrHydA} 1$ in the $\mathrm{H}_{\text {sred }} \mathrm{H}^{+}$ state in $\mathrm{H}_{2} \mathrm{O}$

Figure S4 | Temperature dependent FTIR of $C r \mathrm{HydA} 1$ in the $\mathrm{H}_{\text {sred }} \mathrm{H}^{+}$state in $\mathrm{D}_{2} \mathrm{O}$

Figure S5 | Temperature dependent FTIR of $\mathrm{CrHydA} 1$ in the $\mathrm{H}_{\text {sred }} \mathrm{H}^{+}$state in $\mathrm{D}_{2} \mathrm{O}$

Figure S6 | Temperature dependent FTIR of $\mathrm{CrHydA1}$ in the $\mathrm{H}_{\text {sred }} \mathrm{H}^{+}$state in $\mathrm{D}_{2} \mathrm{O}$ before spline curve fitting for background subtraction

Figure S7 | $\mathrm{H}_{2} \mathrm{O} / \mathrm{D}_{2} \mathrm{O}$ dependent FTIR peak shifts of $C r \mathrm{HydA} 1 \mathrm{H}_{\text {sred }} \mathrm{H}^{+}$state at $40 \mathrm{~K}$

Figure S8 | Temperature dependent FTIR of $D d \mathrm{HydAB}$ in the $\mathrm{H}_{\text {red }} \mathrm{H}^{+}$state in $\mathrm{H}_{2} \mathrm{O}$

Figure S9 | Temperature dependent FTIR of $D d \mathrm{HydAB}$ in the $\mathrm{H}_{\mathrm{red}} \mathrm{H}^{+}$state in $\mathrm{H}_{2} \mathrm{O}$ before spline curve fitting for background subtraction

Figure S10 | Temperature dependent FTIR of $D d \mathrm{HydAB}$ in the $\mathrm{H}_{\text {red }} \mathrm{H}^{+}$state in $\mathrm{D}_{2} \mathrm{O}$

Figure S11 | Temperature dependent FTIR of $D d \mathrm{HydAB}$ in the $\mathrm{H}_{\text {red }} \mathrm{H}^{+}$state in $\mathrm{D}_{2} \mathrm{O}$

Figure S12 | Temperature dependent FTIR of $D d \mathrm{HydAB}$ in the $\mathrm{H}_{\mathrm{red}} \mathrm{H}^{+}$state in $\mathrm{D}_{2} \mathrm{O}$ before spline curve fitting for background subtraction

Figure $\mathrm{S} 13 \mid \mathrm{H}_{2} \mathrm{O} / \mathrm{D}_{2} \mathrm{O}$ dependent FTIR peak shifts of $D d \mathrm{HydAB}_{\mathrm{red}} \mathrm{H}^{+}$state at $40 \mathrm{~K}$

Figure S14 | Structures of the $\mu \mathrm{CO}$ and $\mu \mathrm{CO}^{+}$states from DFT modeling

Figure S15 | Structures of the $\mu \mathrm{H}$ and $\mu \mathrm{H}^{+}$states from DFT modeling

Figure S16 | Structural comparison of the $\mu \mathrm{CO}^{+}$and $\mu \mathrm{H}^{+}$states from DFT modeling

Figure S17 | Structural comparison of the $\mu \mathrm{CO}$ and $\mu \mathrm{H}$ states from DFT modeling

Figure $\mathrm{S} 18$ | Comparison of $\mathrm{H}_{2} \mathrm{O} / \mathrm{D}_{2} \mathrm{O}$ effect on DFT models of FTIR spectra of the $\mathrm{H}_{\text {red }} \mathrm{H}^{+}$state and the $\mathrm{H}_{\text {sred }} \mathrm{H}^{+}$state Figure S19 | NRVS of CrHydA1 and $D d \mathrm{HydAB}$ in the $\mathrm{H}_{\text {sred }} \mathrm{H}^{+}$and $\mathrm{H}_{\mathrm{red}} \mathrm{H}^{+}$states with error bars

Figure S20 ${ }^{57} \mathrm{Fe}-\mathrm{PVDOS}$ spectra from DFT calculations on the $\mu \mathrm{CO}^{+}, \mu \mathrm{CO}, \mathrm{H}_{\text {hyd }}, \mu \mathrm{H}^{+}$, and $\mu \mathrm{H}$ model states overlaid with the available NRVS experimental data

Figure S21 | DFT calculations of the NRVS spectrum of the $\mathrm{H}_{\text {sred }} \mathrm{H}^{+}$state with experimental error bars

Figure S22 | Comparison of $\mathrm{H}_{2} \mathrm{O} / \mathrm{D}_{2} \mathrm{O}$ effect on DFT models of NRVS spectra of the $\mathrm{H}_{\mathrm{red}} \mathrm{H}^{+}$state

Figure S23 | DFT calculations of the NRVS spectrum of the $\mathrm{H}_{\mathrm{red}} \mathrm{H}^{+}$state with experimental error bars

Figure S24 | Comparison of $\mathrm{H}_{2} \mathrm{O} / \mathrm{D}_{2} \mathrm{O}$ effect on DFT models of NRVS spectra of the $\mathrm{H}_{\mathrm{red}} \mathrm{H}^{+}$state

Figure S25 ${ }^{57} \mathrm{Fe}-\mathrm{PVDOS}$ spectra of the $\mathrm{H}_{\mathrm{red}} \mathrm{H}^{+}, \mathrm{H}_{\text {sred }} \mathrm{H}^{+}$, and $\mathrm{H}_{\text {hyd }}$ states from NRVS experiments and DFT models

\section{Supplementary Tables}

Table S1 | Temperature dependent peak positions and line widths of IR spectra of the $\mathrm{H}_{\text {sred }} \mathrm{H}^{+}$state from $\mathrm{CrHydA1}$ and the $\mathrm{H}_{\mathrm{red}} \mathrm{H}^{+}$state from $D d \mathrm{HydAB}$

Table S2 | Metal-ligand $\mathrm{Fe}_{\mathrm{d} / \mathrm{p}}-\mathrm{C} / \mathrm{H}$ internuclear distances in alternative states from DFT modeling

Table S3 | Formal descriptions and relative energies of alternative DFT model states

Table S4 | Experimental and calculated IR band frequencies of the $\mathrm{H}_{\text {red }} \mathrm{H}^{+}$and $\mathrm{H}_{\text {sred }} \mathrm{H}^{+}$states and their assignment to the $\mathrm{CO} / \mathrm{CN}^{-}$ligands on the proximal and distal $\mathrm{Fe}$ sites

Table S5 $\mid\left\langle[2 \mathrm{Fe}]_{\mathrm{H}}\right\rangle,\left\langle[4 \mathrm{Fe}-4 \mathrm{~S}]_{\mathrm{H}}\right\rangle$, and $\langle$ Protein $>$ molecular fragments charge and spin populations in alternative DFT model states

\section{Supplementary Discussion}

What's in a name: [FeFe] hydrogenase H-cluster state nomenclature

Extended details on the DFT results and modeling

\section{Supplementary References}




\section{Supplementary Figures}

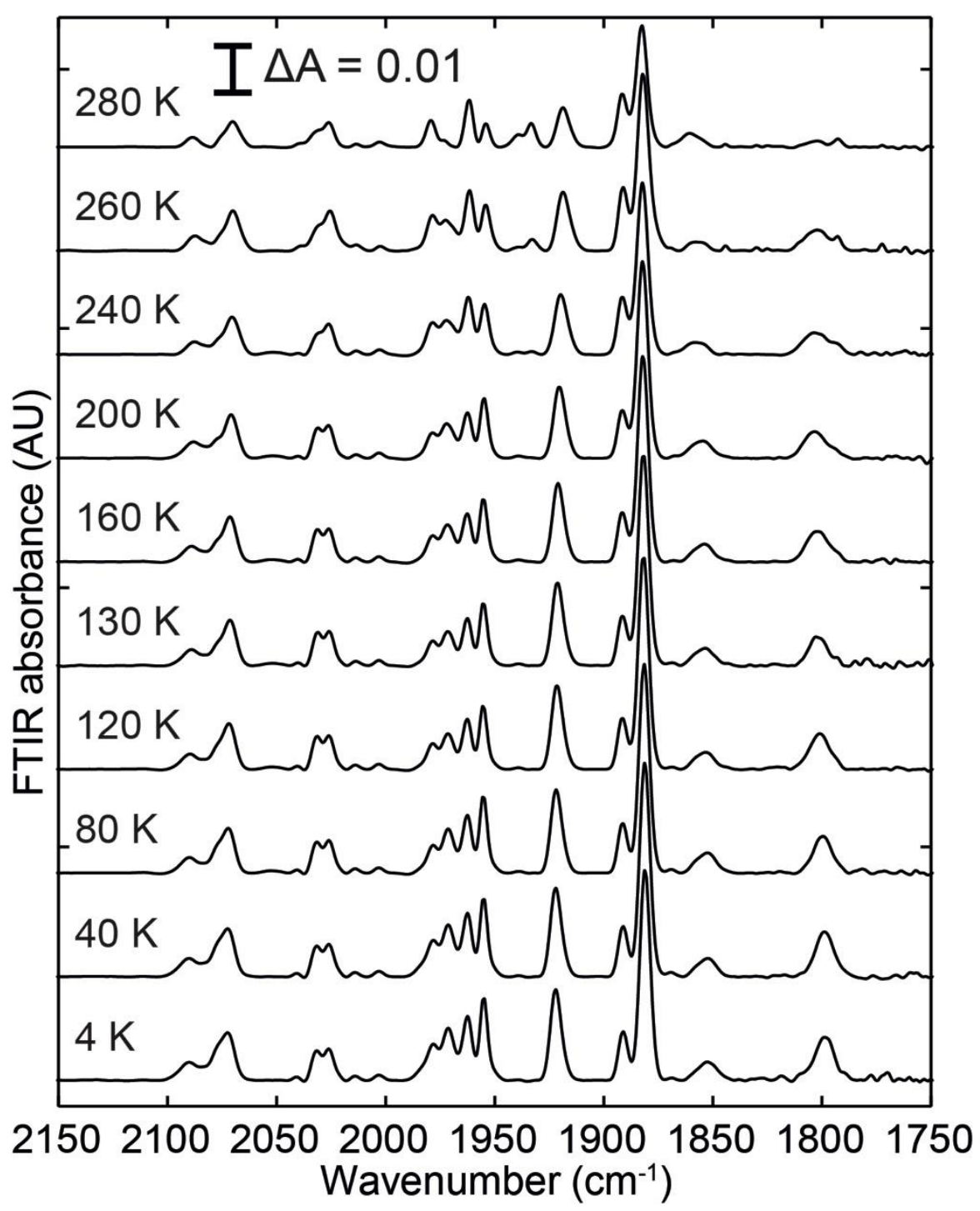

Figure S1 | Temperature dependent FTIR of $\mathrm{CrHydA1}$ in the $\mathrm{H}_{\text {sred }} \mathrm{H}^{+}$state in $\mathrm{H}_{2} \mathrm{O}$. Lowtemperature FTIR spectra of $\mathrm{CrHydA} 1$ in the $\mathrm{H}_{\text {sred }} \mathrm{H}^{+}$state in $\mathrm{H}_{2} \mathrm{O}$ buffer reduced with $20 \mathrm{mM}$ sodium dithionite. 


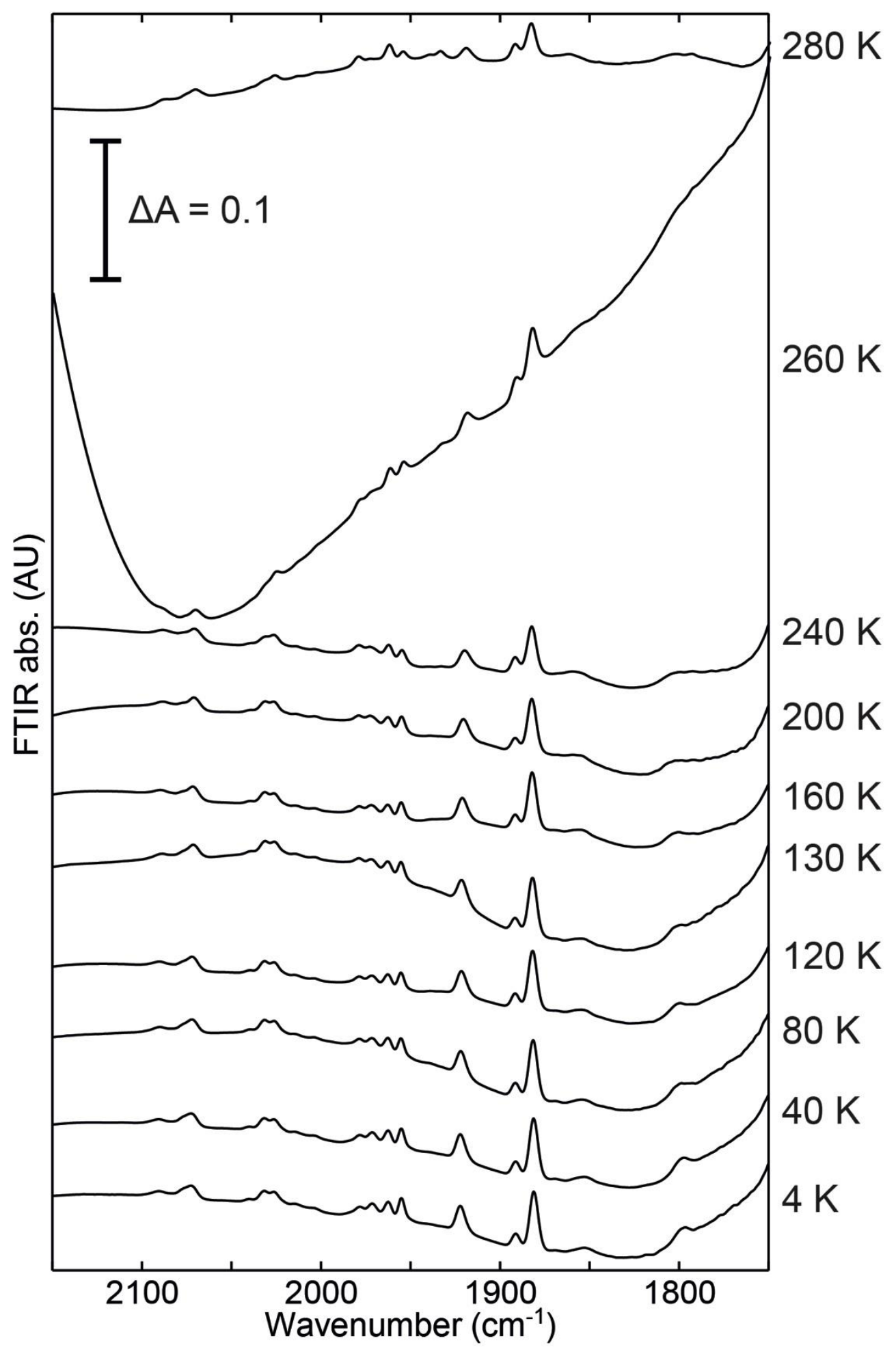

Figure S2 | Temperature dependent FTIR of $\mathrm{CrHydA1}$ in the $\mathrm{H}_{\text {sred }} \mathrm{H}^{+}$state in $\mathrm{H}_{2} \mathrm{O}$ before spline curve fitting for background subtraction. 


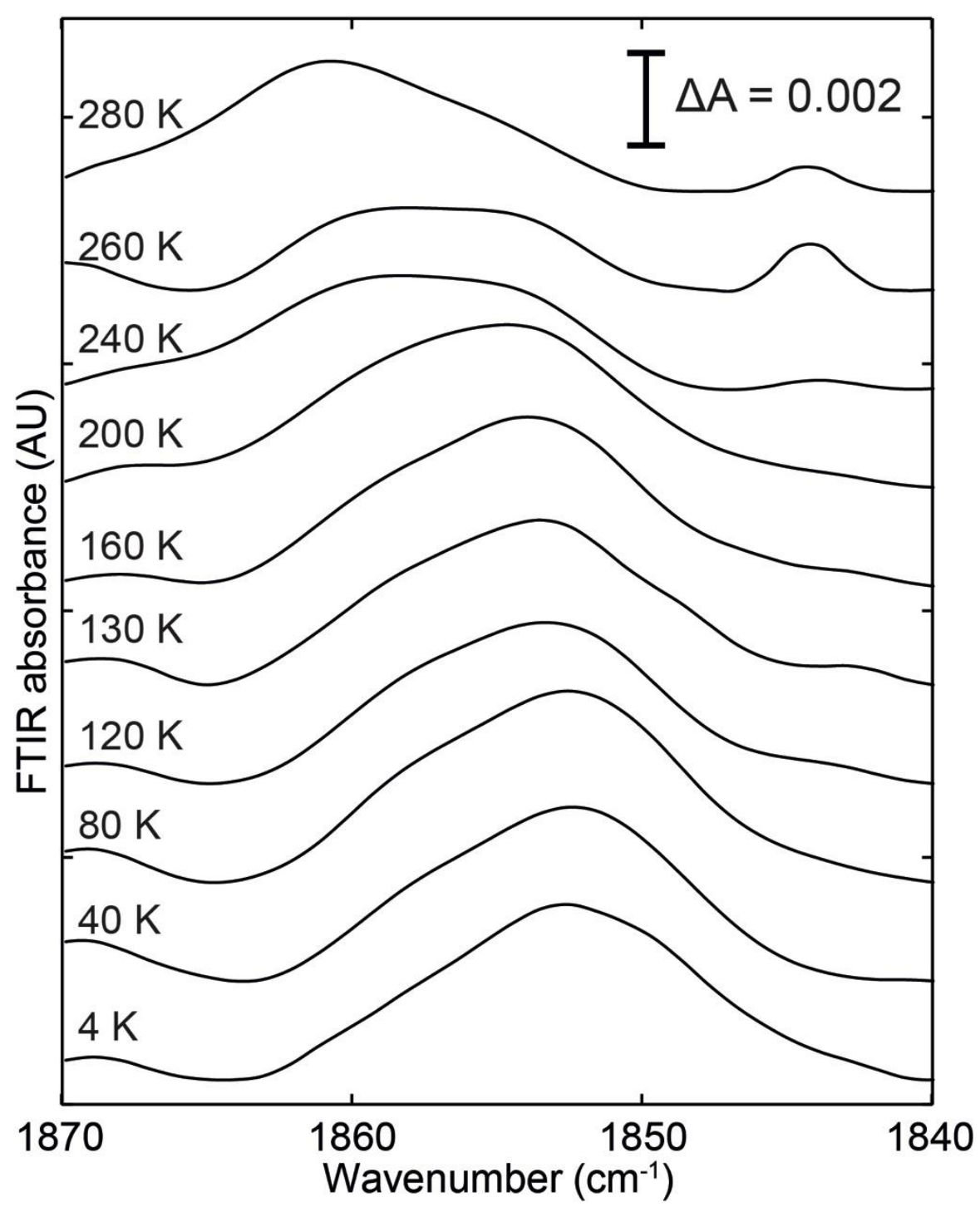

Figure S3 | Close up of the $\mathrm{H}_{\text {hyd }}$ bridging $\mathrm{CO}$ region in the temperature dependent FTIR of CrHydA1 in the $\mathrm{H}_{\text {sred }} \mathrm{H}^{+}$state in $\mathrm{H}_{2} \mathrm{O}$. The low-temperature FTIR spectra of $\mathrm{CrHydA1}$ in the $\mathrm{H}_{\text {sred }} \mathrm{H}^{+}$state in $\mathrm{H}_{2} \mathrm{O}$ buffer reduced with $20 \mathrm{mM}$ sodium dithionite shown in Figure S1 are presented with the region between 1840 and $1870 \mathrm{~cm}^{-1}$ expanded. 


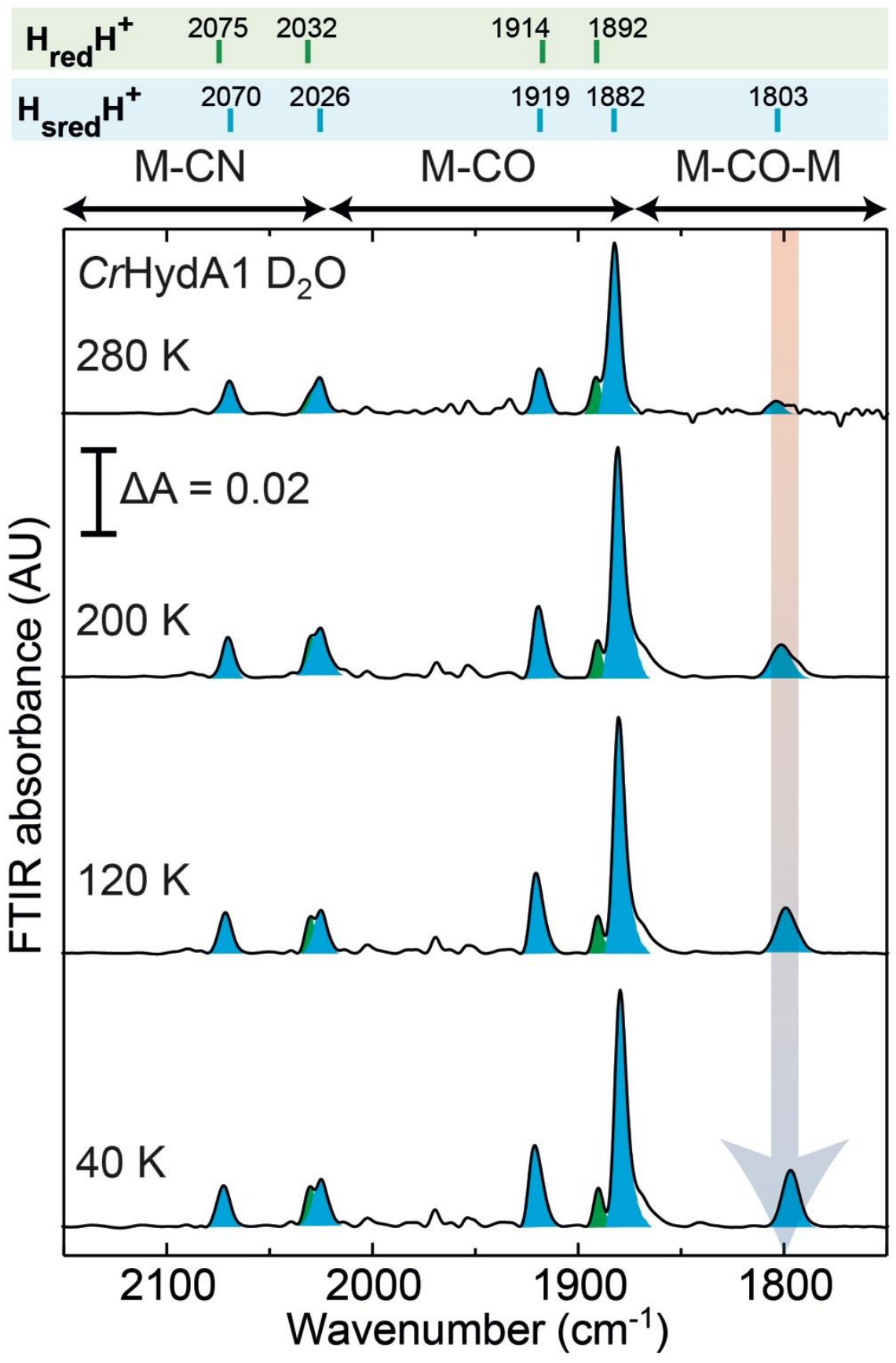

Figure S4 | Temperature dependent FTIR of $\mathrm{CrHydA1}$ in the $\mathrm{H}_{\text {sred }} \mathrm{H}^{+}$state in $\mathrm{D}_{2} \mathrm{O}$. Lowtemperature FTIR spectra of $C r \mathrm{HydA} 1$ in the $\mathrm{H}_{\text {sred }} \mathrm{H}^{+}$state in $\mathrm{D}_{2} \mathrm{O}$ buffer reduced with $20 \mathrm{mM}$ sodium dithionite. The peaks corresponding to the $\mathrm{H}_{\text {sred }} \mathrm{H}^{+}$state are colored blue. Smaller contributions from the $\mathrm{H}_{\text {red }} \mathrm{H}^{+}$state $(10 \%)$ are colored green. 


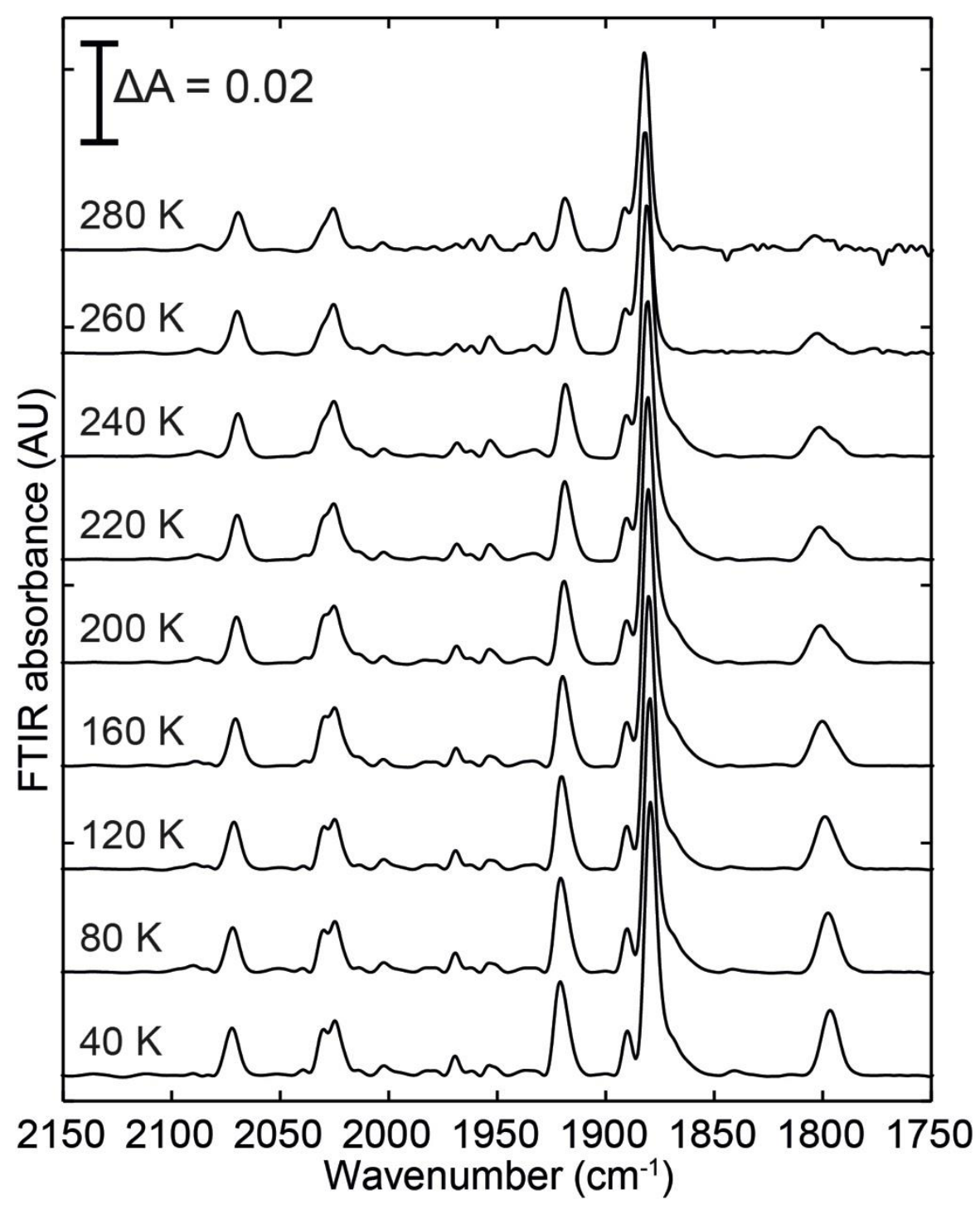

Figure S5 | Temperature dependent FTIR of $\mathrm{CrHydA1}$ in the $\mathrm{H}_{\text {sred }} \mathrm{H}^{+}$state in $\mathrm{D}_{2} \mathrm{O}$. Lowtemperature FTIR spectra of $\mathrm{CrHydA} 1$ in the $\mathrm{H}_{\text {sred }} \mathrm{H}^{+}$state in $\mathrm{D}_{2} \mathrm{O}$ buffer reduced with $20 \mathrm{mM}$ sodium dithionite. 


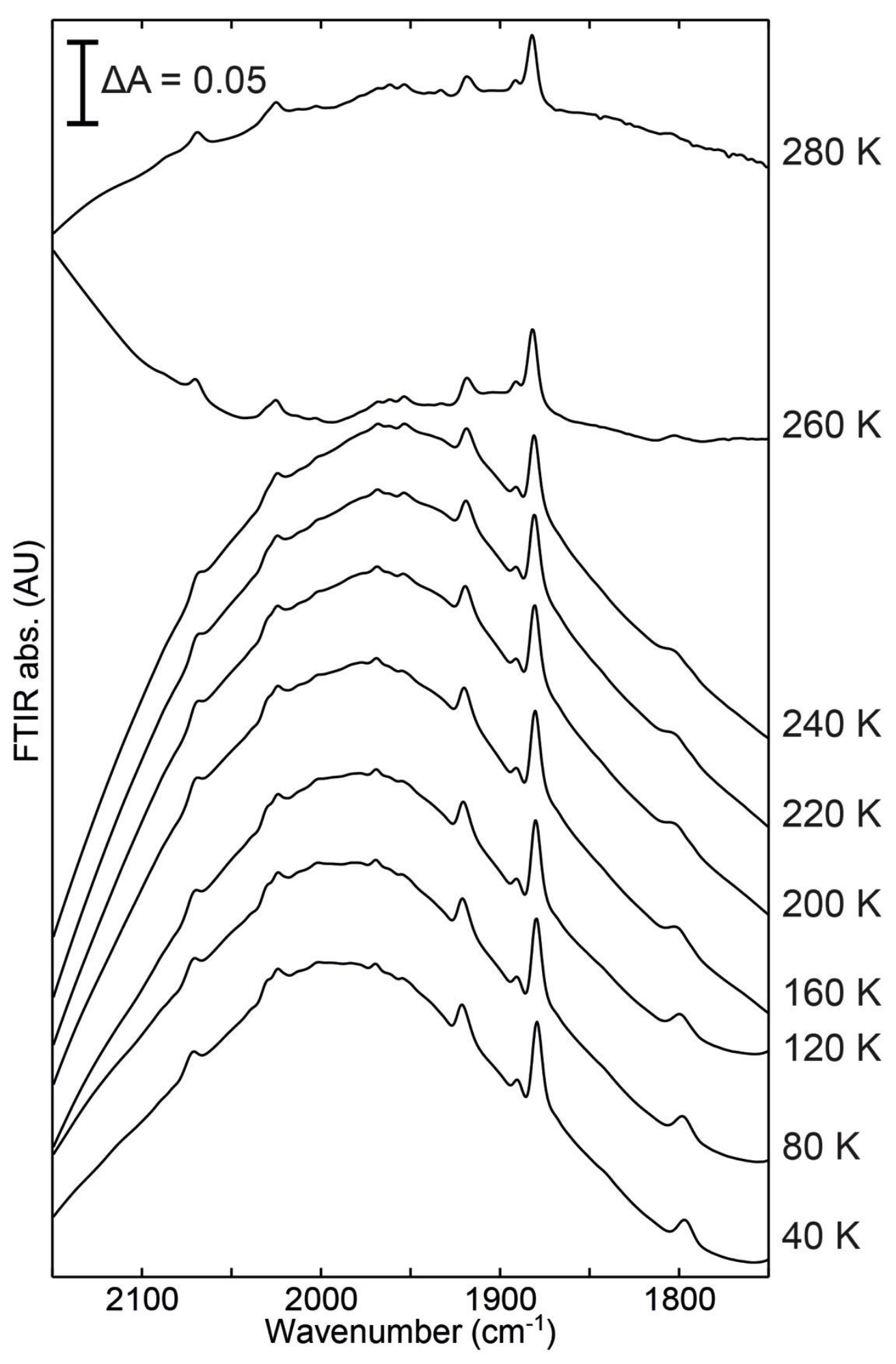

Figure S6 | Temperature dependent FTIR of $\mathrm{CrHydA1}$ in the $\mathrm{H}_{\text {sred }} \mathrm{H}^{+}$state in $\mathrm{D}_{2} \mathrm{O}$ before spline curve fitting for background subtraction. 

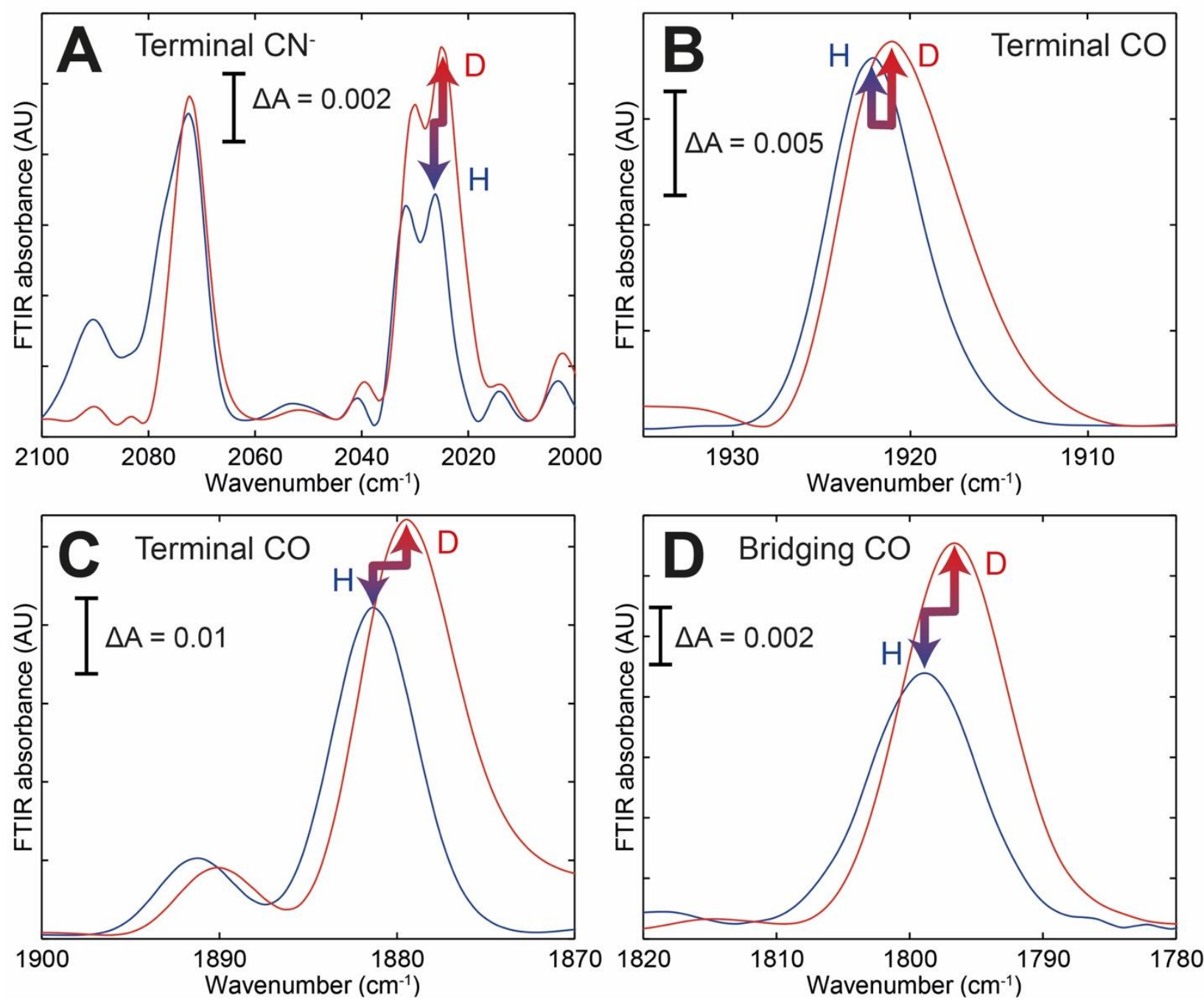

Figure S7 | $\mathrm{H}_{2} \mathrm{O} / \mathrm{D}_{2} \mathrm{O}$ dependent FTIR peak shifts of $\mathrm{CrHydA1} \mathrm{H}_{\text {sred }} \mathrm{H}^{+}$state at $40 \mathrm{~K}$. FTIR spectra measured at $40 \mathrm{~K}$ of $\mathrm{CrHydA} 1$ in the $\mathrm{H}_{\text {sred }} \mathrm{H}^{+}$state reduced with $20 \mathrm{mM}$ sodium dithionite in $\mathrm{H}_{2} \mathrm{O}$ buffer (blue lines) are compared with those in $\mathrm{D}_{2} \mathrm{O}$ buffer. Panels $\mathbf{A}-\mathbf{D}$ show the regions corresponding to A) the two terminal $\mathrm{CN}^{-}$ligands $\left.\left(2000-2100 \mathrm{~cm}^{-1}\right), \mathbf{B}\right)$ one of the terminal $\mathrm{CO}$ ligands (1905-1935 $\left.\mathrm{cm}^{-1}\right)$, C) the other terminal CO ligand $\left(1870-1900 \mathrm{~cm}^{-1}\right)$, and D) the bridging $\mathrm{CO}$ ligand $\left(1780-1820 \mathrm{~cm}^{-1}\right)$. Arrows indicate the observed shifts in energy upon $\mathrm{H}_{2} \mathrm{O}$ to $\mathrm{D}_{2} \mathrm{O}$ exchange. 


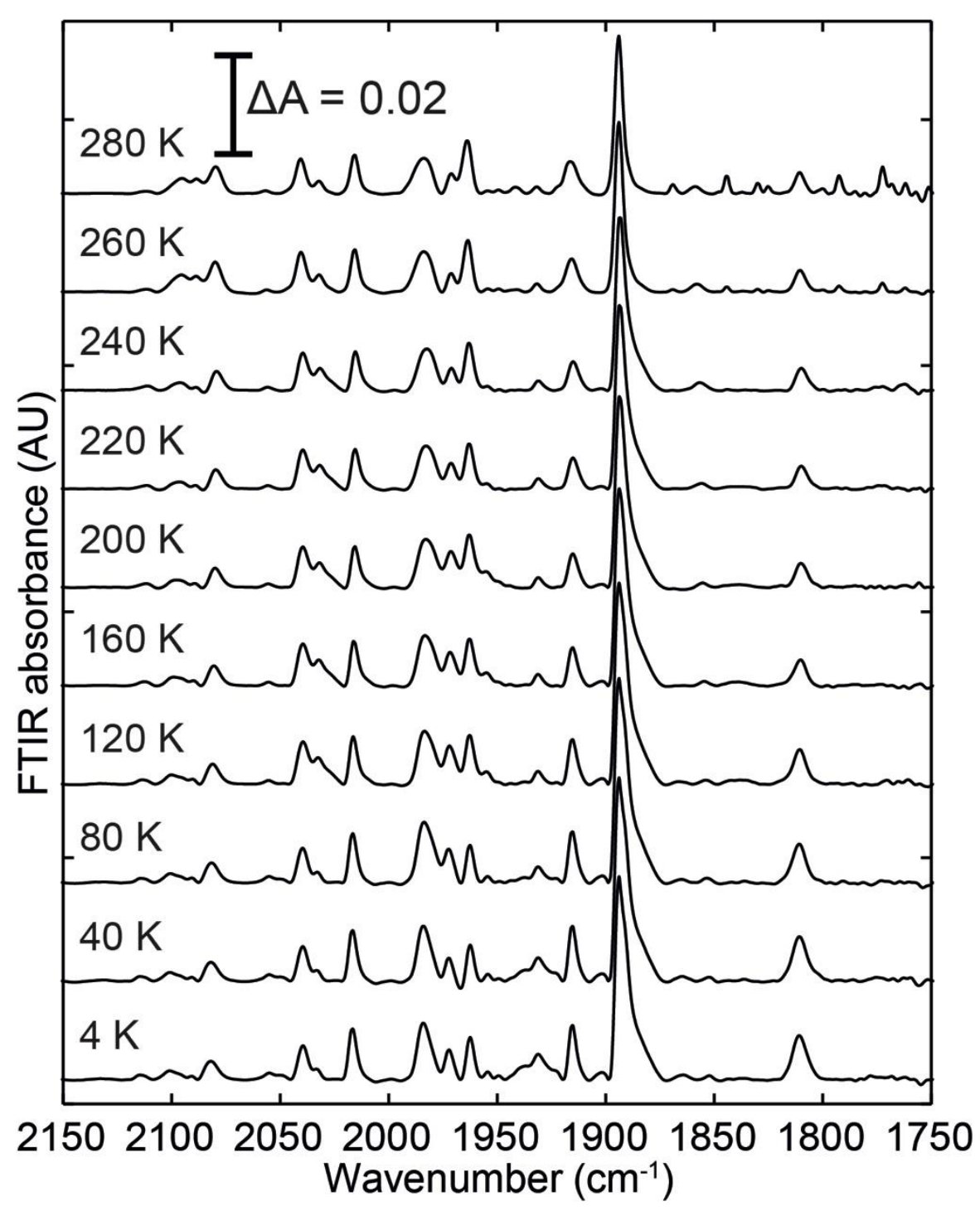

Figure S8 | Temperature dependent FTIR of $\mathrm{DdHydAB}$ in the $\mathrm{H}_{\text {red }} \mathrm{H}^{+}$state in $\mathrm{H}_{2} \mathrm{O}$. Lowtemperature FTIR spectra of $D d \mathrm{HydAB}$ in the $\mathrm{H}_{\mathrm{red}} \mathrm{H}^{+}$state in $\mathrm{H}_{2} \mathrm{O}$ buffer reduced with $20 \mathrm{mM}$ sodium dithionite. 


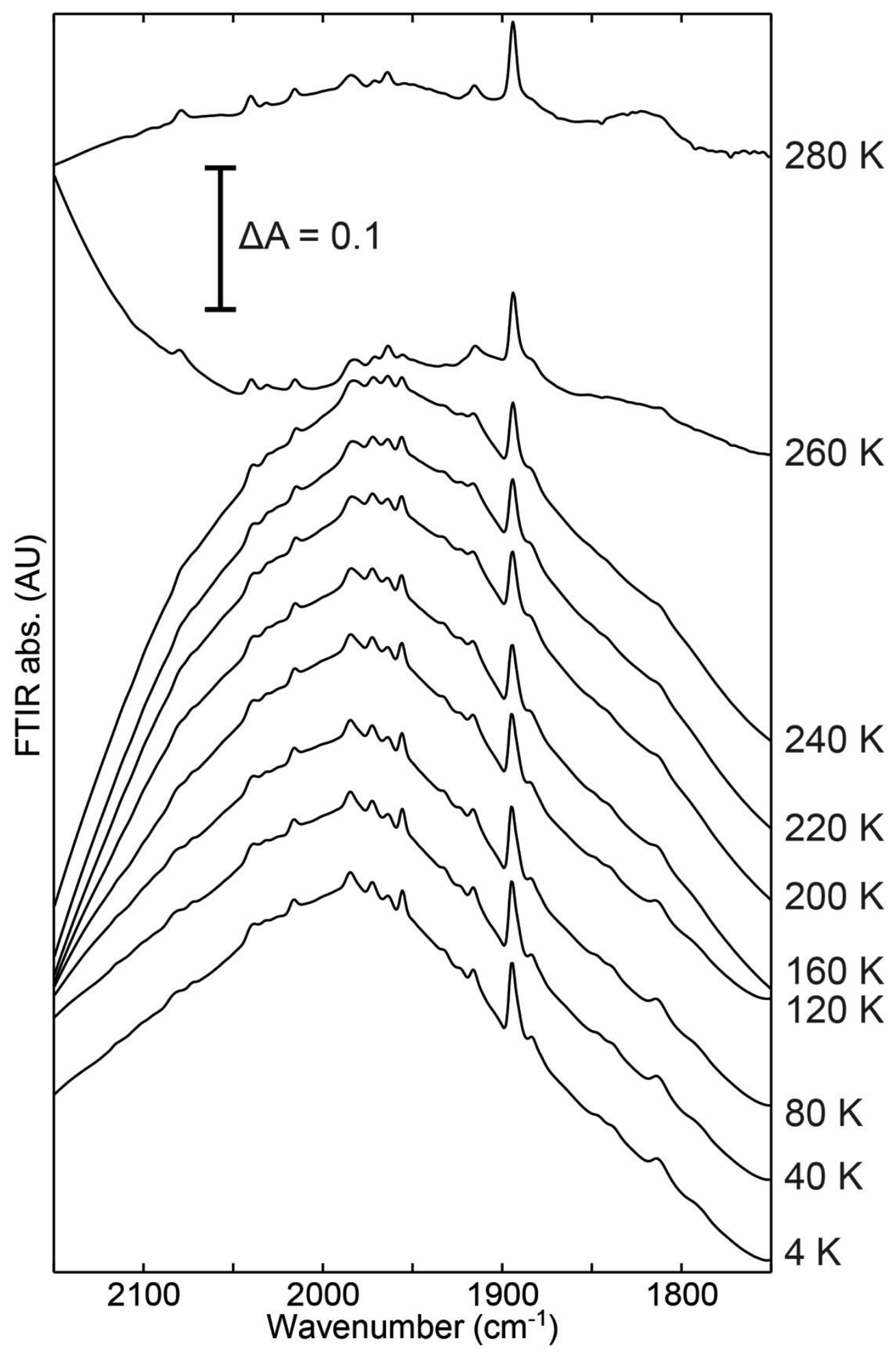

Figure S9 | Temperature dependent FTIR of $D d \mathrm{HydAB}$ in the $\mathrm{H}_{\mathrm{red}} \mathrm{H}^{+}$state in $\mathrm{H}_{2} \mathrm{O}$ before spline curve fitting for background subtraction. 


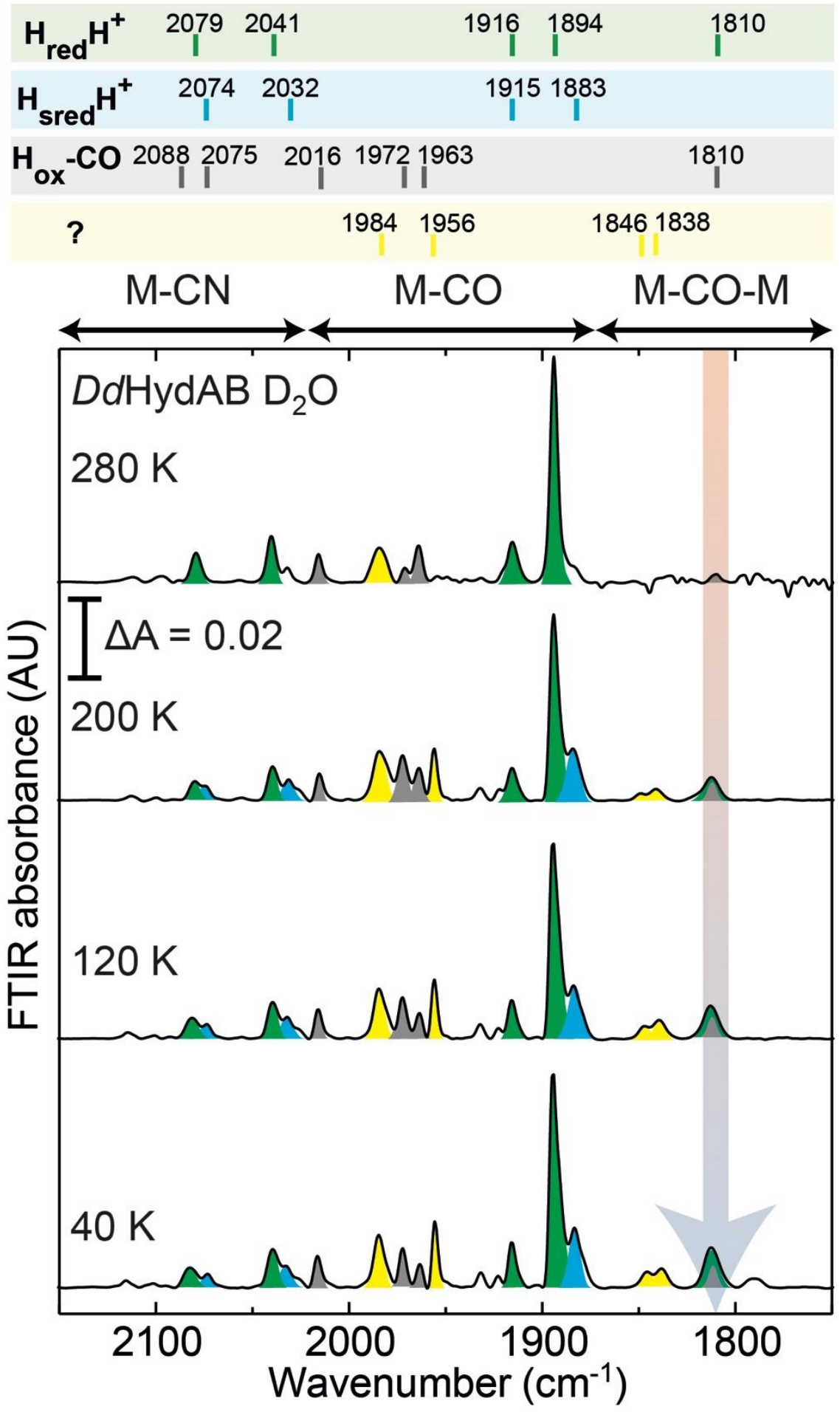

Figure S10 | Temperature dependent FTIR of $\mathrm{DdHydAB}$ in the $\mathrm{H}_{\mathrm{red}} \mathrm{H}^{+}$state in $\mathrm{D}_{2} \mathrm{O}$. Lowtemperature FTIR spectra of $D d \mathrm{HydAB}$ in the $\mathrm{H}_{\mathrm{red}} \mathrm{H}^{+}$state in $\mathrm{D}_{2} \mathrm{O}$ buffer reduced with $20 \mathrm{mM}$ sodium dithionite. The peaks corresponding to the $\mathrm{H}_{\mathrm{red}} \mathrm{H}^{+}$state are colored green. Small contributions from the $\mathrm{H}_{\text {sred }} \mathrm{H}^{+}$state, the $\mathrm{H}_{\text {ox }}-\mathrm{CO}$ state, and an uncharacterized state are colored purple, gray, and yellow, respectively. 


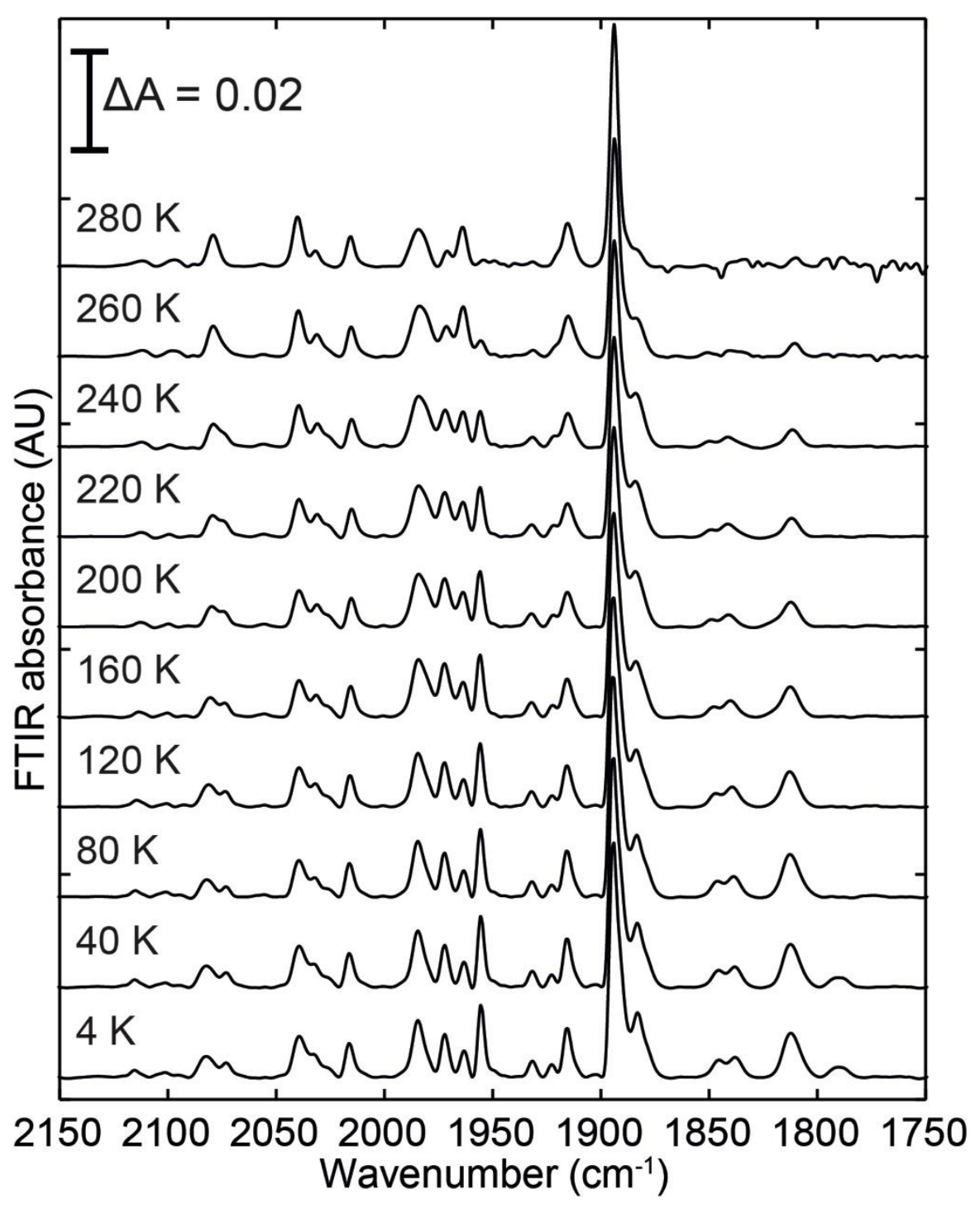

Figure S11 | Temperature dependent FTIR of $\mathrm{DdHydAB}$ in the $\mathrm{Hred}^{+}$state in $\mathrm{D}_{2} \mathrm{O}$. Lowtemperature FTIR spectra of $D d \mathrm{HydAB}$ in the $\mathrm{H}_{\mathrm{red}} \mathrm{H}^{+}$state in $\mathrm{D}_{2} \mathrm{O}$ buffer reduced with $20 \mathrm{mM}$ sodium dithionite. 


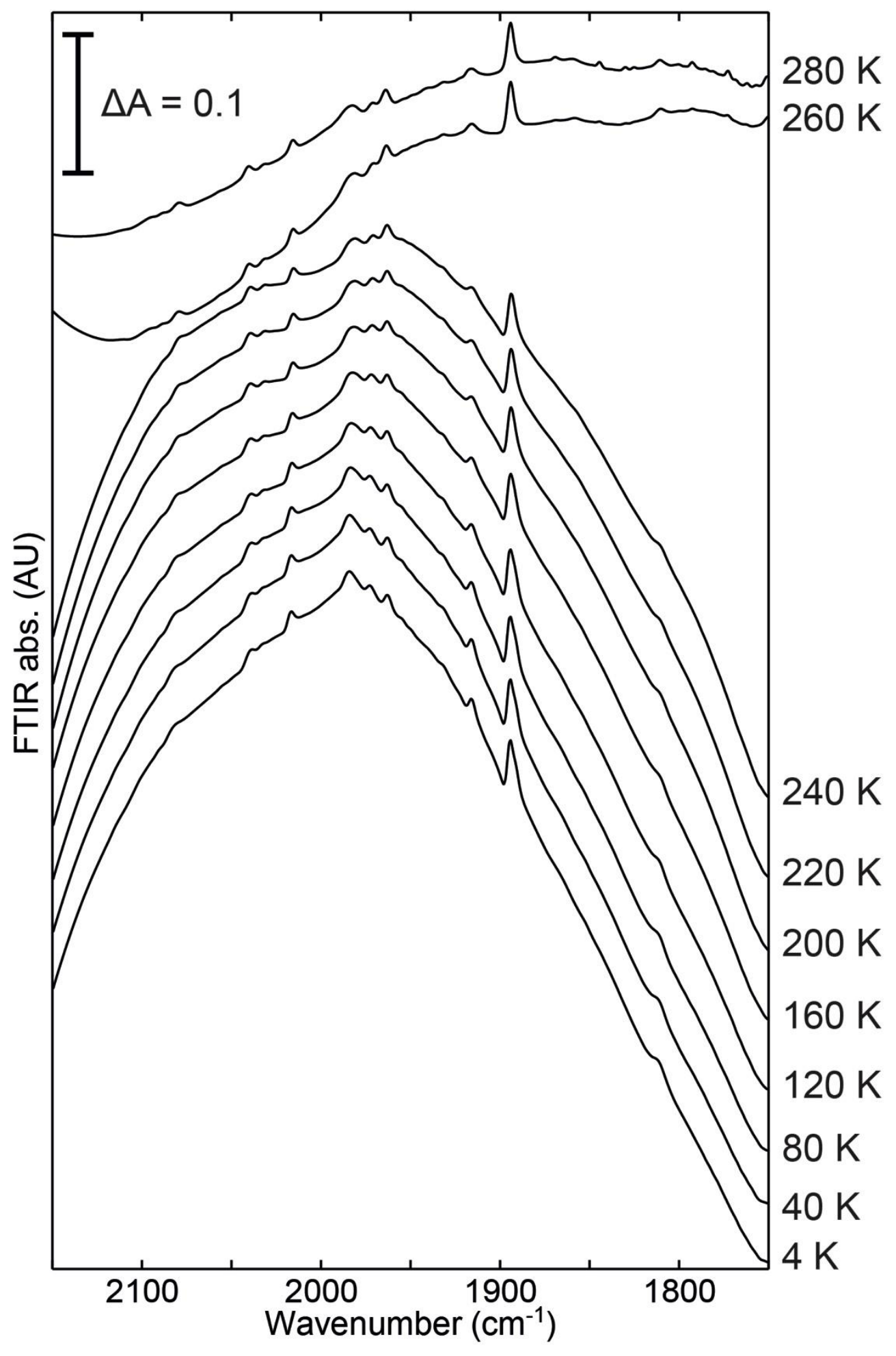

Figure S12 | Temperature dependent FTIR of $D d \mathrm{HydAB}$ in the $\mathrm{Hred}^{+}$state in $\mathrm{D}_{2} \mathrm{O}$ before spline curve fitting for background subtraction. 

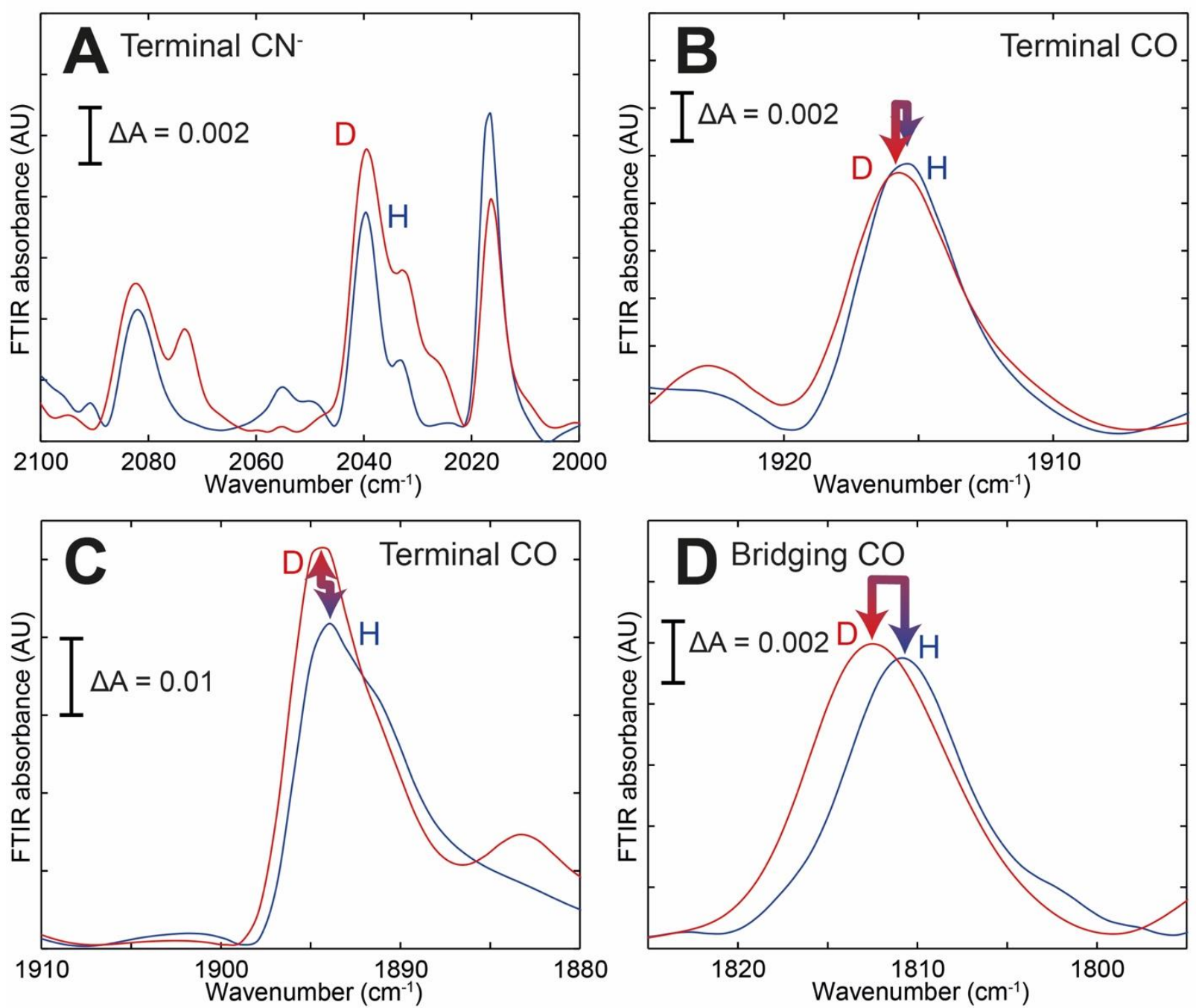

Figure $\mathrm{S} 13$ | $\mathrm{H}_{2} \mathrm{O} / \mathrm{D}_{2} \mathrm{O}$ dependent FTIR peak shifts of $\mathrm{DdHydAB} \mathrm{H}_{\text {red }} \mathrm{H}^{+}$state at $40 \mathrm{~K}$. FTIR spectra measured at $40 \mathrm{~K}$ of $D d \mathrm{HydAB}$ in the $\mathrm{H}_{\mathrm{red}} \mathrm{H}^{+}$state reduced with $20 \mathrm{mM}$ sodium dithionite in $\mathrm{H}_{2} \mathrm{O}$ buffer (blue lines) are compared with those in $\mathrm{D}_{2} \mathrm{O}$ buffer. Panels $\mathbf{A}-\mathbf{D}$ show the regions corresponding to A) the two terminal $\mathrm{CN}^{-}$ligands $\left.\left(2000-2100 \mathrm{~cm}^{-1}\right), \mathbf{B}\right)$ one of the terminal $\mathrm{CO}$ ligands (1905-1925 $\left.\mathrm{cm}^{-1}\right)$, C) the other terminal CO ligand $\left(1880-1910 \mathrm{~cm}^{-1}\right)$, and D) the bridging $\mathrm{CO}$ ligand $\left(1795-1825 \mathrm{~cm}^{-1}\right)$. Arrows indicate the observed shifts in energy upon $\mathrm{H}_{2} \mathrm{O}$ to $\mathrm{D}_{2} \mathrm{O}$ exchange. 


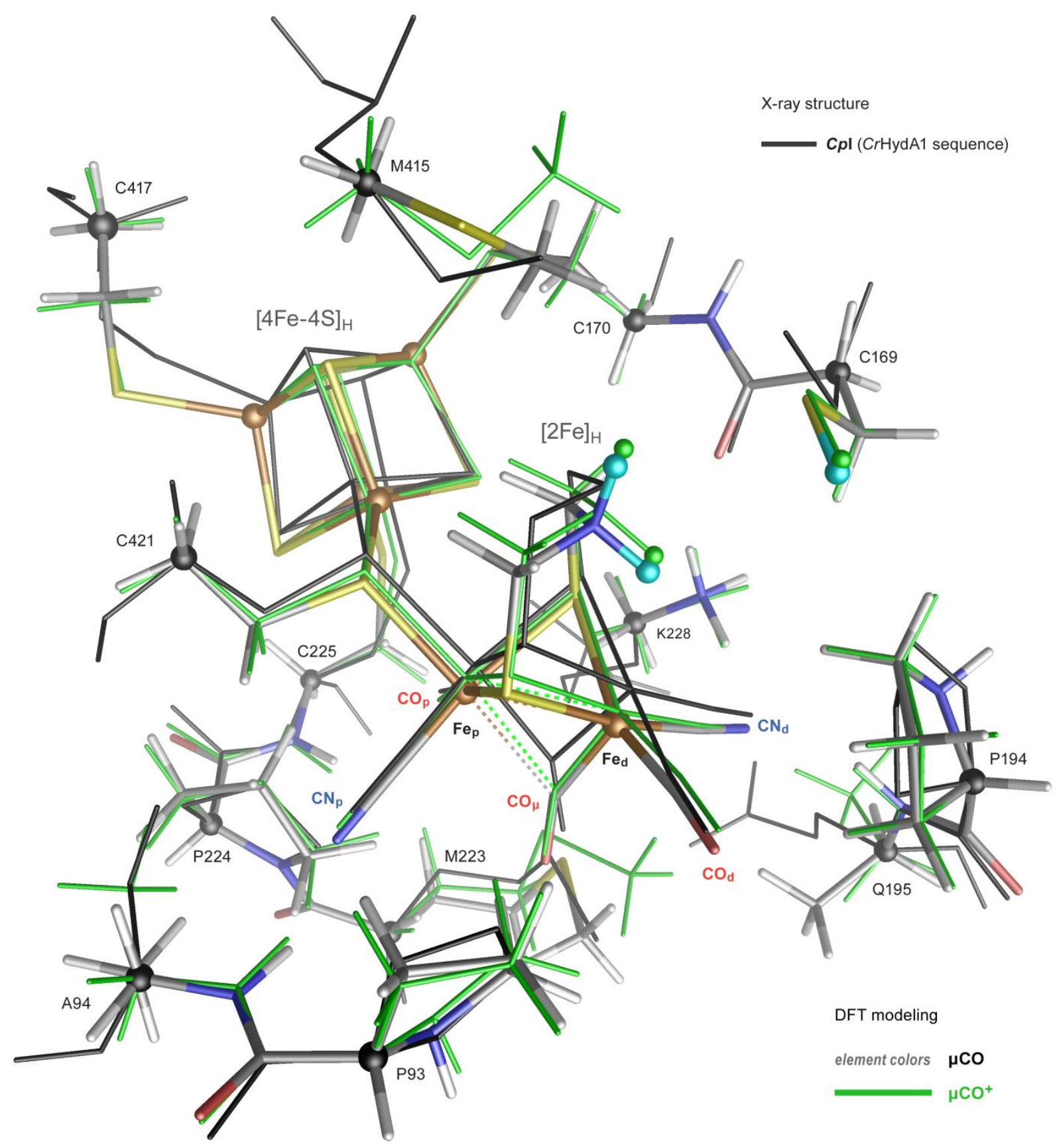

Figure S14 | Structures of the $\boldsymbol{\mu C O}$ (element colors, tube representation) and $\boldsymbol{\mu} \mathbf{C O}^{+}$(green, thin tube) DFT models, overlaid together with their X-ray reference PDB 5BYQ (black, thin tube). Additionally, in ball representation are indicated the carbon nuclei locked to their original X-ray positions during DFT structural optimization, Fe sites, and the three H-to-D exchangeable protons. Single-letter amino acid labeling corresponds to the $\mathrm{CrHydA} 1$ enzyme sequence. 


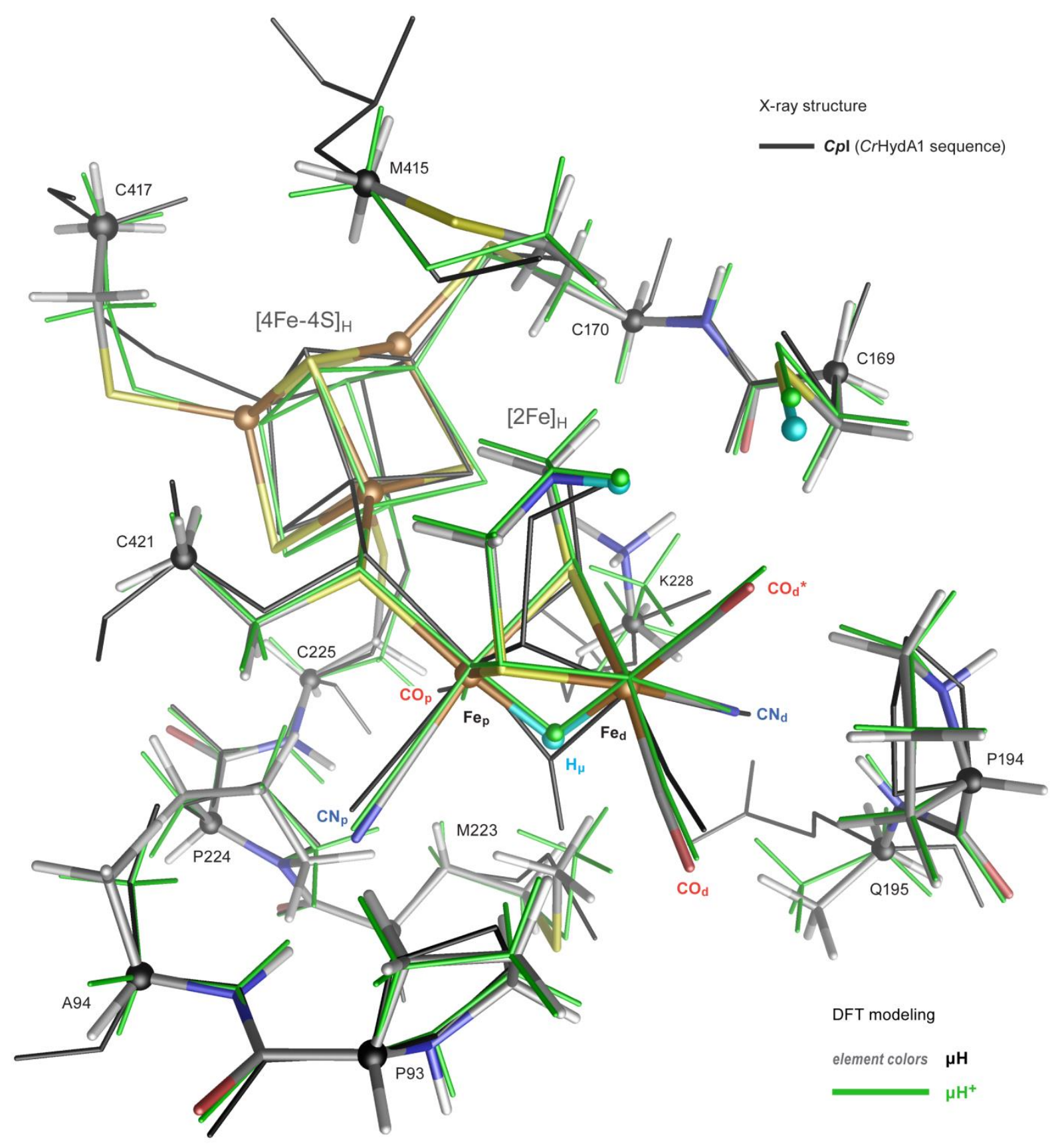

Figure S15 | Structures of the $\boldsymbol{\mu H}$ (element colors, tube representation) and $\boldsymbol{\mu H}^{+}$(green, thin tube) DFT models, overlaid together with their X-ray reference PDB 5BYQ (black, thin tube). Additionally, in ball representation are indicated the carbon nuclei locked to their original X-ray positions during DFT structural optimization, Fe sites, and the three H-to-D exchangeable protons. Single-letter amino acid labeling corresponds to the $C r H y d A 1$ enzyme sequence. 


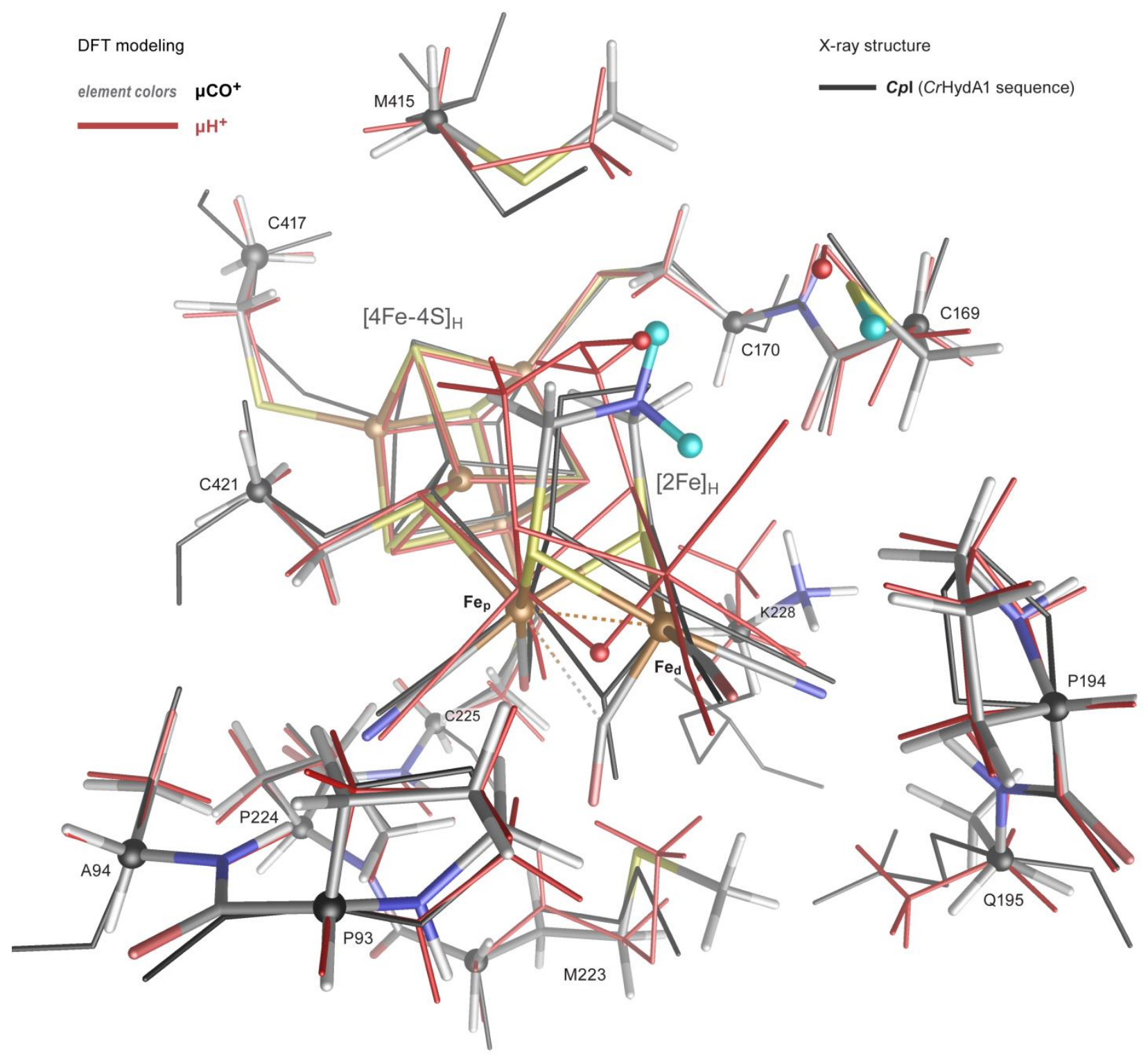

Figure S16 | Structural comparison of the $\boldsymbol{\mu C O}^{+}$(element colors, tube representation) and $\boldsymbol{\mu} \mathbf{H}^{+}$ (red, thin tube) isoelectronic DFT models, overlaid together with their X-ray reference PDB 5BYQ (black, thin tube). Additionally, in ball representation are indicated the carbon nuclei locked to their original X-ray positions during DFT structural optimization, Fe sites, and the three H-to-D exchangeable protons. Single-letter amino acid labeling corresponds to the $\mathrm{CrHydA} 1$ enzyme sequence. 


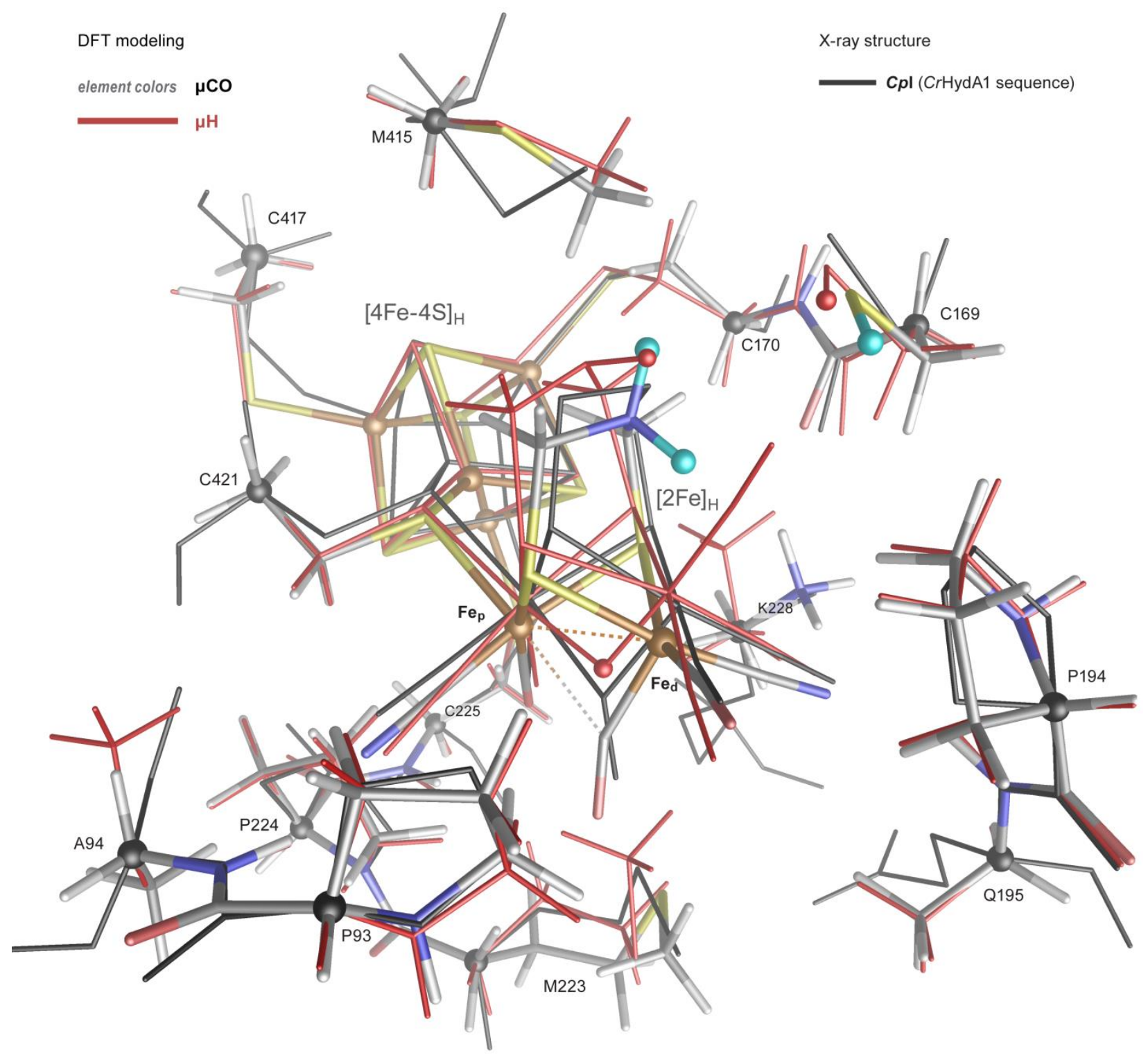

Figure S17 | Structural comparison of the $\boldsymbol{\mu C O}$ (element colors, tube representation) and $\boldsymbol{\mu H}$ (red, thin tube) isoelectronic DFT models, overlaid together with their X-ray reference PDB 5BYQ (black, thin tube). Additionally, in ball representation are indicated the carbon nuclei locked to their original X-ray positions during DFT structural optimization, Fe sites, and the three H-to-D exchangeable protons. Single-letter amino acid labeling corresponds to the $\mathrm{CrHydA} 1$ enzyme sequence. 


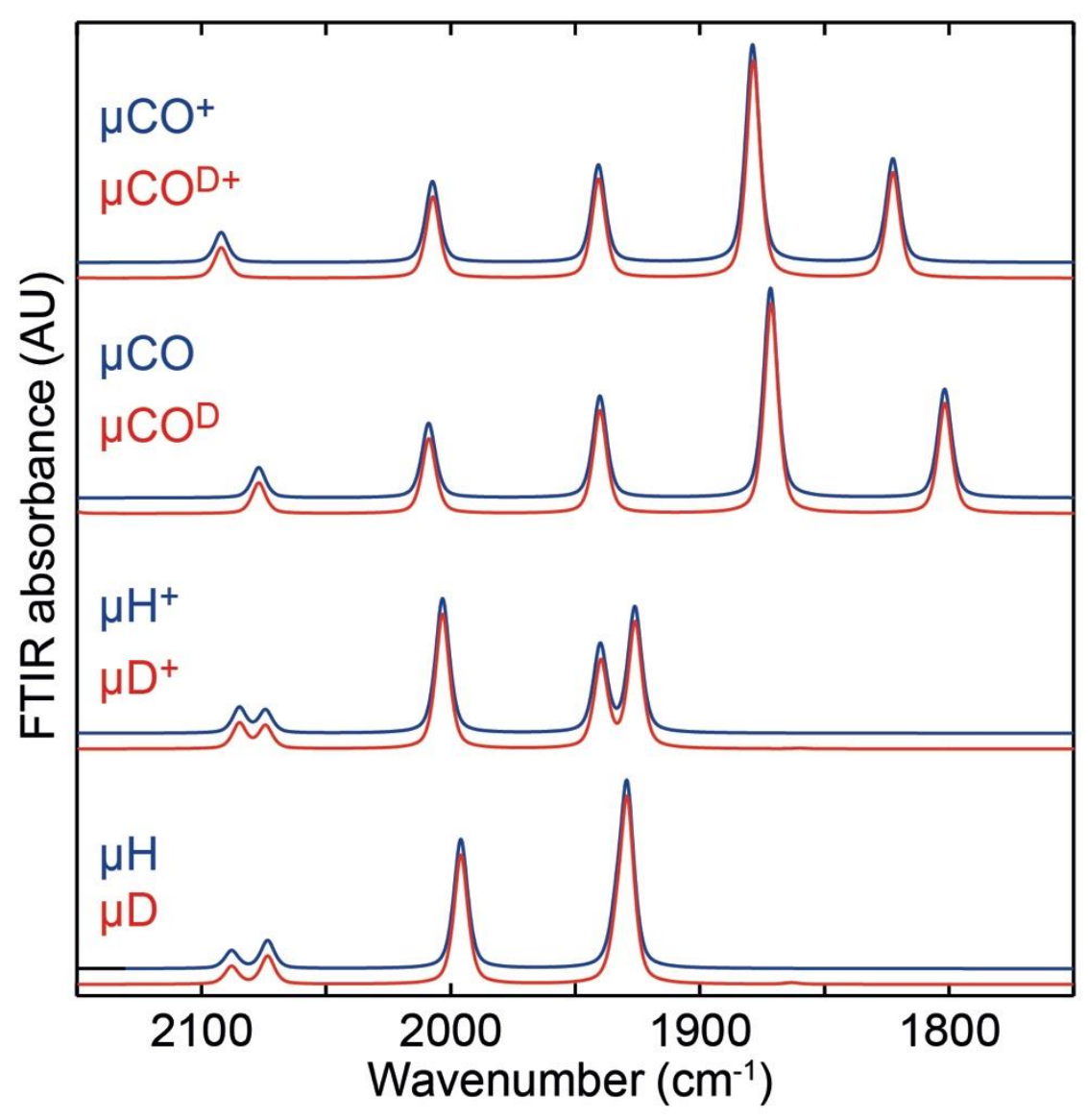

Figure S18 | Comparison of $\mathrm{H}_{2} \mathrm{O} / \mathrm{D}_{2} \mathrm{O}$ effect on DFT models of FTIR spectra of the $\mathrm{H}_{\mathrm{red}} \mathrm{H}^{+}$ state and the $\mathrm{H}_{\text {sred }} \mathrm{H}^{+}$state. FTIR spectra were calculated using DFT (as described in the methods section) with a semibridging $\mathrm{CO}\left(\mu \mathrm{CO}^{+} / \mu \mathrm{CO}^{\mathrm{D}+}\right.$ and $\left.\mu \mathrm{CO} / \mu \mathrm{CO}^{\mathrm{D}}\right)$ model or a bridging hydride $\left(\mu \mathrm{H}^{+} / \mathrm{D}^{+}\right.$and $\left.\mu \mathrm{H} / \mathrm{D}\right)$ model of the protonated (blue lines) and the deuterated (red lines) form of the $\mathrm{H}_{\mathrm{red}} \mathrm{H}^{+}$and $\mathrm{H}_{\text {sred }} \mathrm{H}^{+}$states. The three $\mathrm{H}$-to-D exchangeable protons in the DFT models are shown in Figures S14-S17. The baselines of the H/D spectra have been offset for clarity. The animated normal modes producing the bands shown here for $\mu \mathrm{CO}^{+}, \mu \mathrm{CO}, \mu \mathrm{H}^{+}$, and $\mu \mathrm{H}$ are available as part of the Supporting Information. 

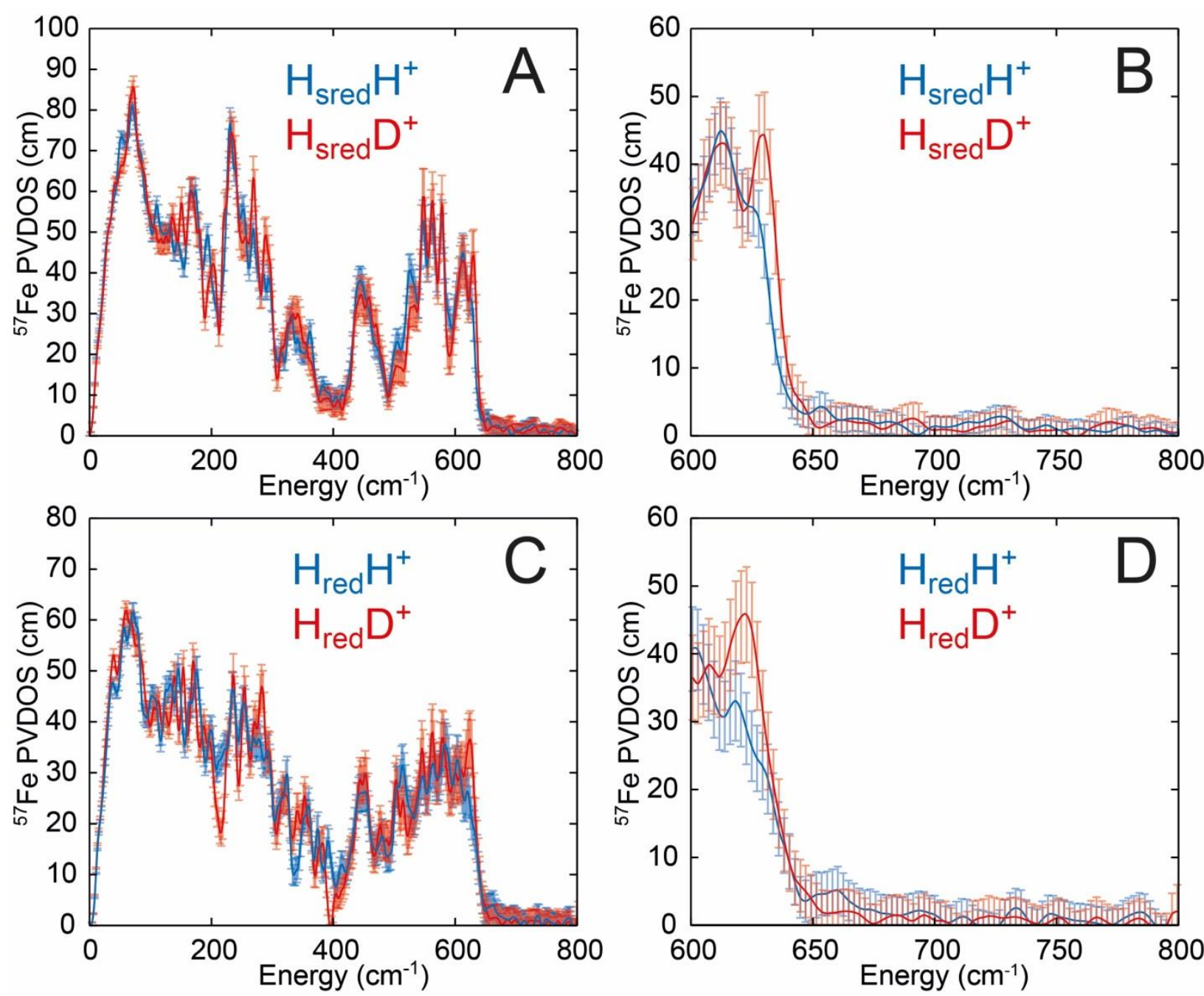

Figure S19 | NRVS of $C r H y d A 1$ and $D d H y d A B$ in the $\mathrm{H}_{\text {sred }} \mathrm{H}^{+}$and $\mathrm{H}_{\text {red }} \mathrm{H}^{+}$states with error bars. Spectra are presented of $\mathrm{CrHydA} 1$ in the $\mathrm{H}_{\text {sred }} \mathrm{H}^{+}$state $\left(\mathbf{A}\right.$ and $\mathbf{B}$ ) in $\mathrm{H}_{2} \mathrm{O}$ buffer (blue traces) and $\mathrm{D}_{2} \mathrm{O}$ buffer (red traces) reduced with $20 \mathrm{mM}$ sodium dithionite. Spectra are presented of $D d \mathrm{HydAB}$ in the $\mathrm{H}_{\text {red }} \mathrm{H}^{+}$state $\left(\mathbf{C}\right.$ and $\mathbf{D}$ ) in $\mathrm{H}_{2} \mathrm{O}$ buffer (blue traces) and $\mathrm{D}_{2} \mathrm{O}$ buffer (red traces) reduced with $20 \mathrm{mM}$ sodium dithionite. $\mathbf{B}$ and $\mathbf{D}$ are expansions of the high energy region from $\mathbf{A}$ and $\mathbf{C}$, respectively. Error bars indicate the standard deviation of $14\left(C r \mathrm{HydA} 1 \mathrm{H}_{\text {sred }} \mathrm{H}^{+}\right)$, $8\left(C r H y d A 1 \mathrm{H}_{\text {sred }} \mathrm{D}^{+}\right), 22\left(D d \mathrm{HydAB} \mathrm{H}_{\mathrm{red}} \mathrm{H}^{+}\right)$and $24\left(D d \mathrm{HydAB} \mathrm{H}_{\mathrm{red}} \mathrm{D}^{+}\right)$scans. 


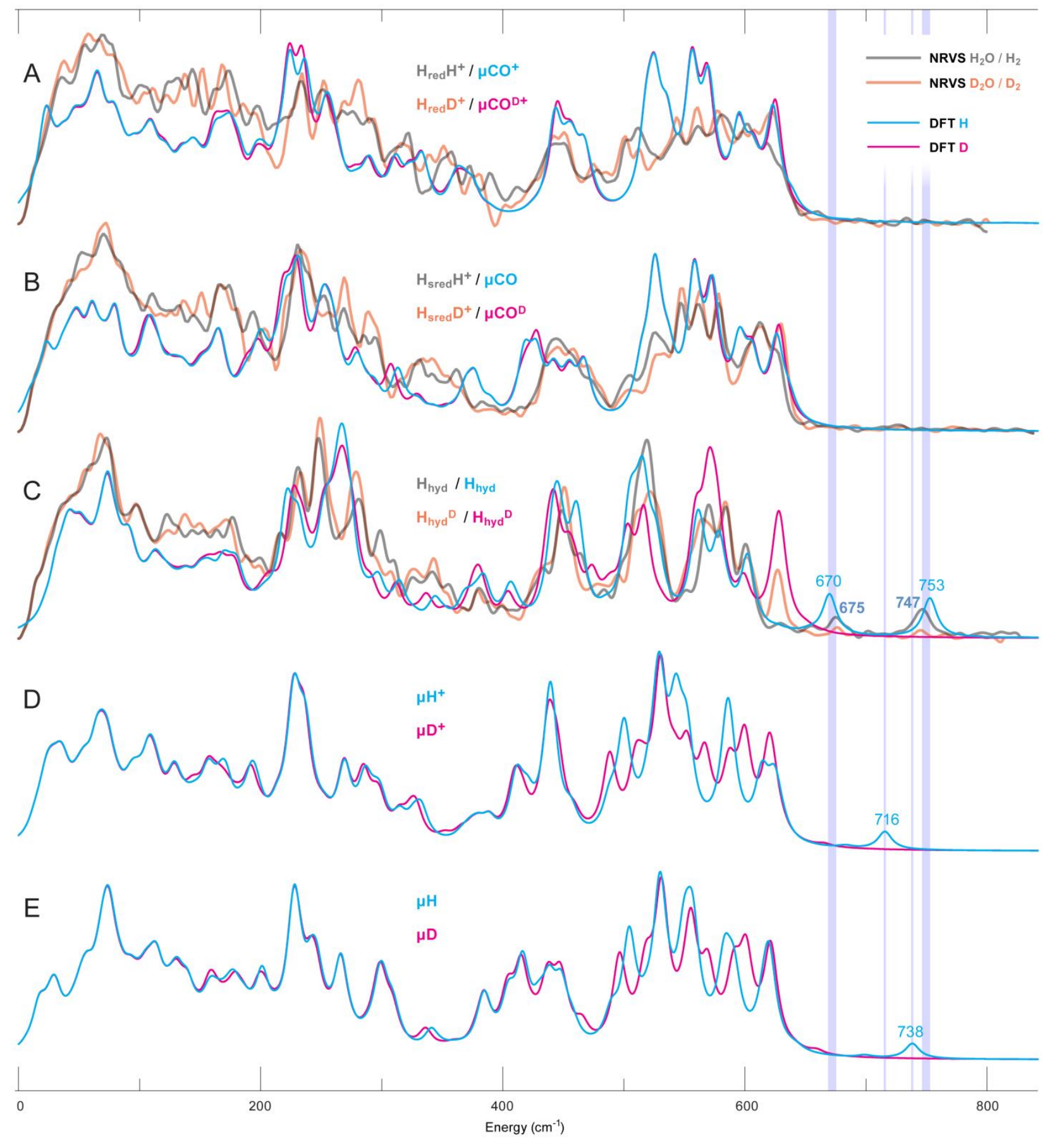

Figure S20 $\mid{ }^{57} \mathrm{Fe}-\mathrm{PVDOS}$ spectra from DFT calculations on the $(\mathbf{A}) \mu \mathrm{CO}^{+},(\mathbf{B}) \mu \mathrm{CO},(\mathbf{C}) \mathrm{H}_{\text {hyd, }}$ (D) $\mu \mathrm{H}^{+}$, and (E) $\mu \mathrm{H}$ model states, overlaid with the available NRVS experimental data in the 0 $800 \mathrm{~cm}^{-1}$ range. The spectra for the unlabeled $(-\mathrm{H})$ and deuterated (-D) NRVS samples / DFT models are correspondingly in gray/cyan and red/magenta. Iron-hydride bands are labeled with their vibrational energies $\left(\mathrm{cm}^{-1}\right)$ and highlighted using vertical bars; the corresponding normal mode animations are available as part of the Supporting Information. The $\mathrm{H}_{\mathrm{red}} \mathrm{H}^{+}$and $\mathrm{H}_{\text {sred }} \mathrm{H}^{+}$ sample NRVS data are from this work, and the $\mathrm{H}_{\text {hyd }}$ data is from $D d \mathrm{HydAB}$ samples and was reported previously. ${ }^{1}$ 

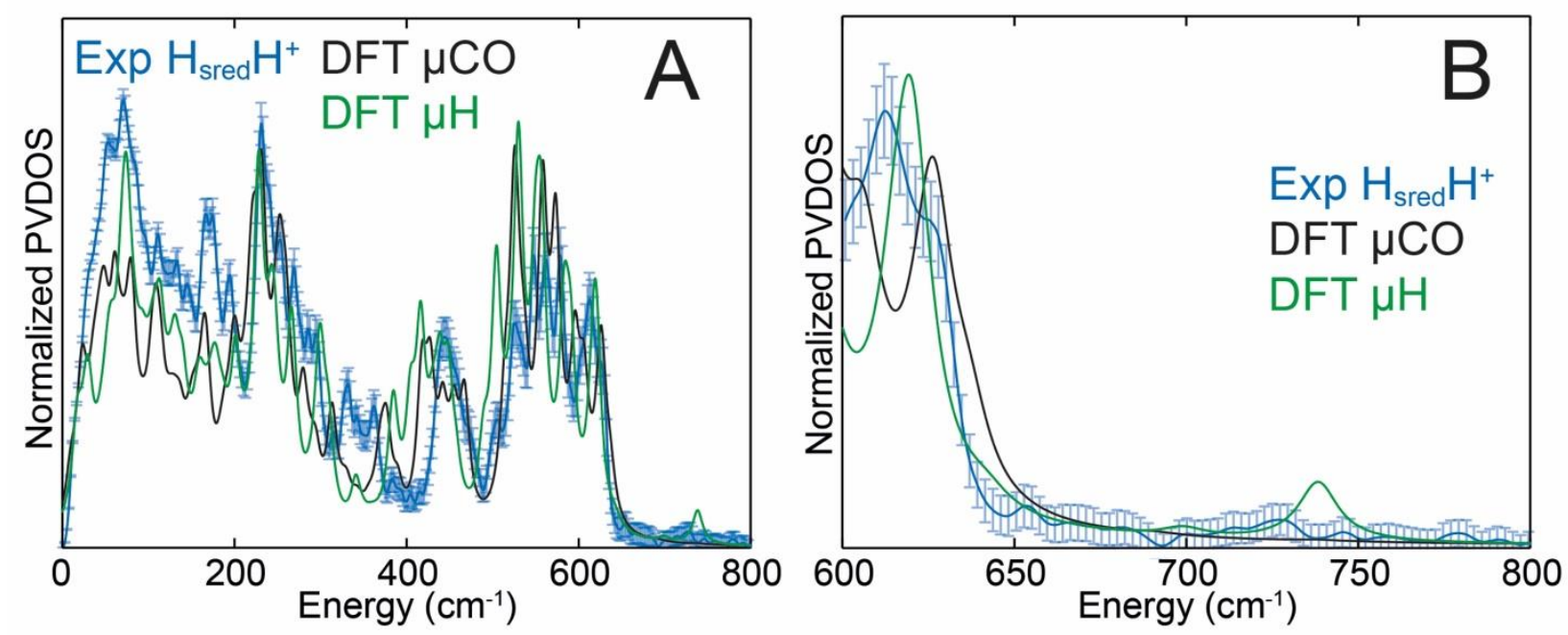

Figure S21 | DFT calculations of the NRVS spectrum of the $\mathrm{H}_{\text {sred }} \mathrm{H}^{+}$state with experimental error bars. The experimental NRVS spectrum of $\mathrm{CrHydA} 1$ in the $\mathrm{H}_{\text {sred }} \mathrm{H}^{+}$state is shown in blue, while the DFT calculated spectrum generated using a bridging $\mathrm{CO}(\mu \mathrm{CO})$ model (Figure 4A, main text) is shown in black, and the DFT calculated spectrum generated using a bridging hydride $(\mu \mathrm{H})$ model (Figure $4 \mathrm{~B}$, main text) is shown in green. $\mathbf{B}$ is an expansion of the high energy region of $\mathbf{A}$. Error bars indicate the standard deviation of 14 scans.
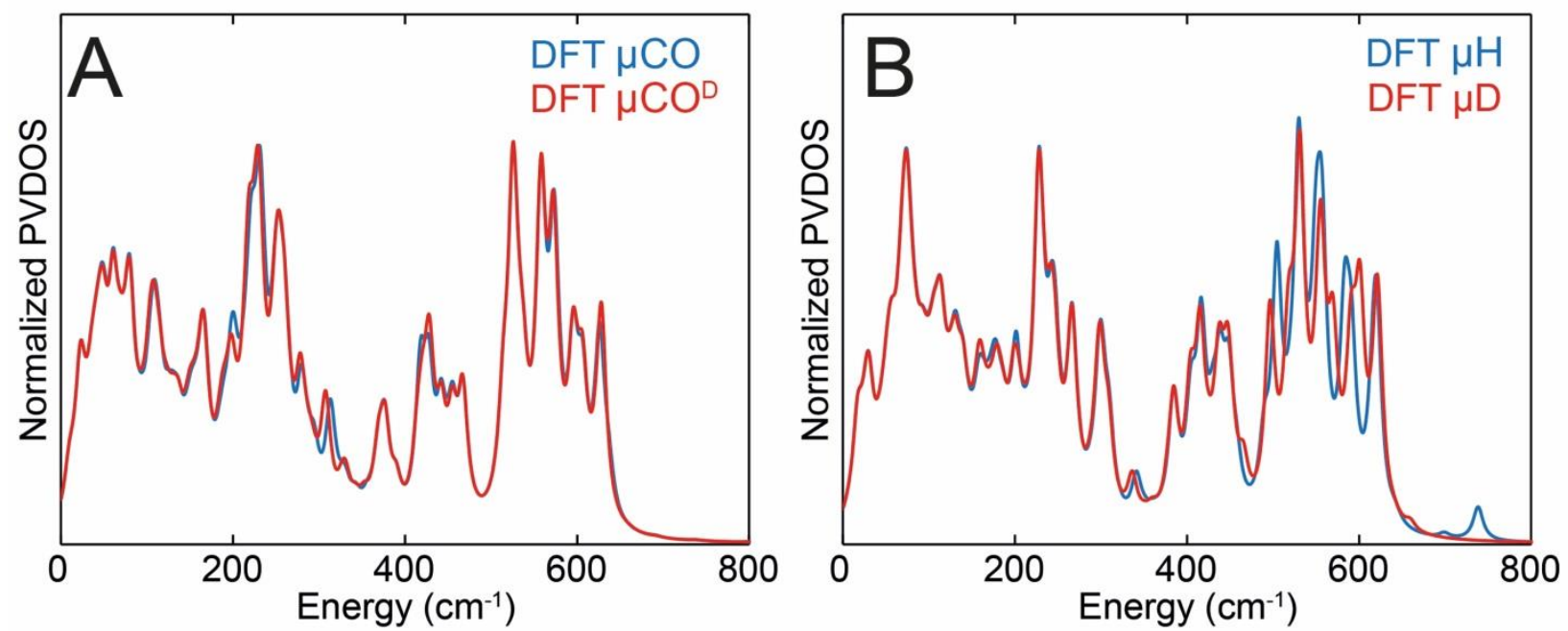

Figure S22 | Comparison of $\mathrm{H}_{2} \mathrm{O} / \mathrm{D}_{2} \mathrm{O}$ effect on DFT models of NRVS spectra of the $\mathrm{H}_{\text {sred }} \mathrm{H}^{+}$ state. NRVS spectra were calculated using DFT (as described in the DFT method section) using a bridging $\mathrm{CO}\left(\mu \mathrm{CO} / \mu \mathrm{CO}^{\mathrm{D}}\right)$ model $(\mathbf{A})$ or a bridging hydride $(\mu \mathrm{H} / \mathrm{D})$ model $(\mathbf{B})$ of the protonated (blue lines) and the deuterated (red lines) forms. 

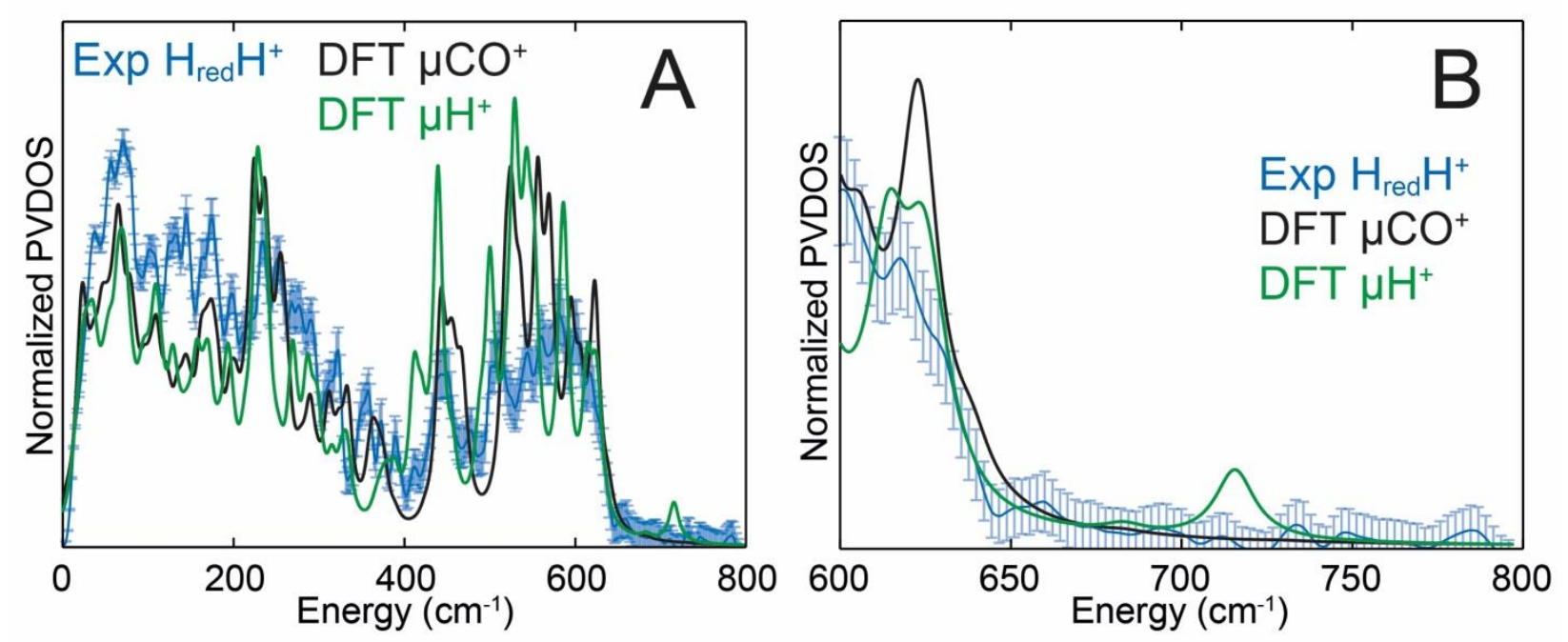

Figure S23 | DFT calculations of the NRVS spectrum of the $\mathrm{H}_{\text {red }} \mathrm{H}^{+}$state with experimental error bars. The experimental NRVS spectrum of $D d \mathrm{HydAB}$ in the $\mathrm{H}_{\mathrm{red}} \mathrm{H}^{+}$state is shown in blue, while the DFT calculated spectrum generated using a bridging $\mathrm{CO}\left(\mu \mathrm{CO}^{+}\right)$model is shown in black, and the DFT calculated spectrum generated using a bridging hydride $\left(\mu \mathrm{H}^{+}\right)$model (Figure $\mathrm{S} 16)$ is shown in green. $\mathbf{B}$ is an expansion of the high energy region of $\mathbf{A}$. Error bars indicate the standard deviation of 22 scans.
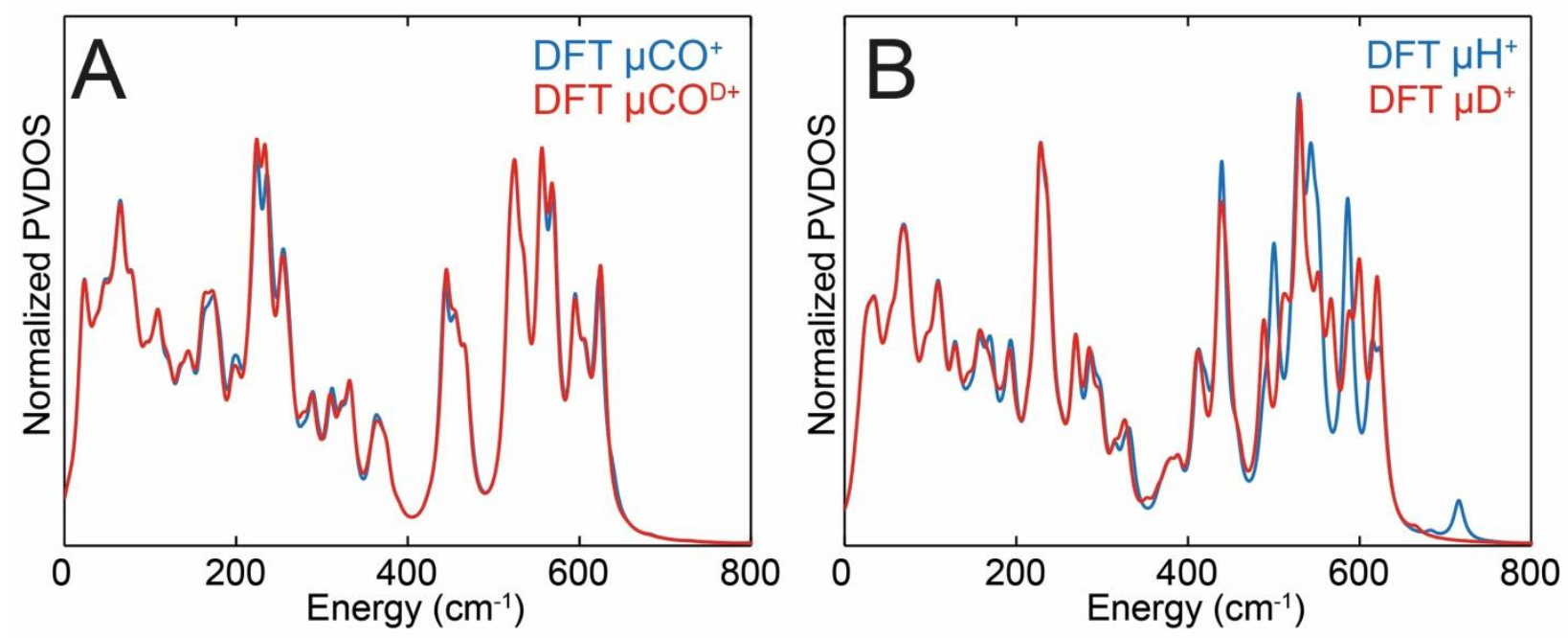

Figure S24 | Comparison of $\mathrm{H}_{2} \mathrm{O} / \mathrm{D}_{2} \mathrm{O}$ effect on DFT models of NRVS spectra of the $\mathrm{H}_{\text {redH}} \mathrm{H}^{+}$ state. NRVS spectra were calculated using DFT (as described in the DFT methods section) using a bridging $\mathrm{CO}\left(\mu \mathrm{CO}^{+} / \mu \mathrm{CO}^{\mathrm{D}+}\right)$ model (A) or a bridging hydride $\left(\mu \mathrm{H}^{+} / \mathrm{D}^{+}\right)$model (B) of the protonated (blue lines) and the deuterated (red lines) forms. 


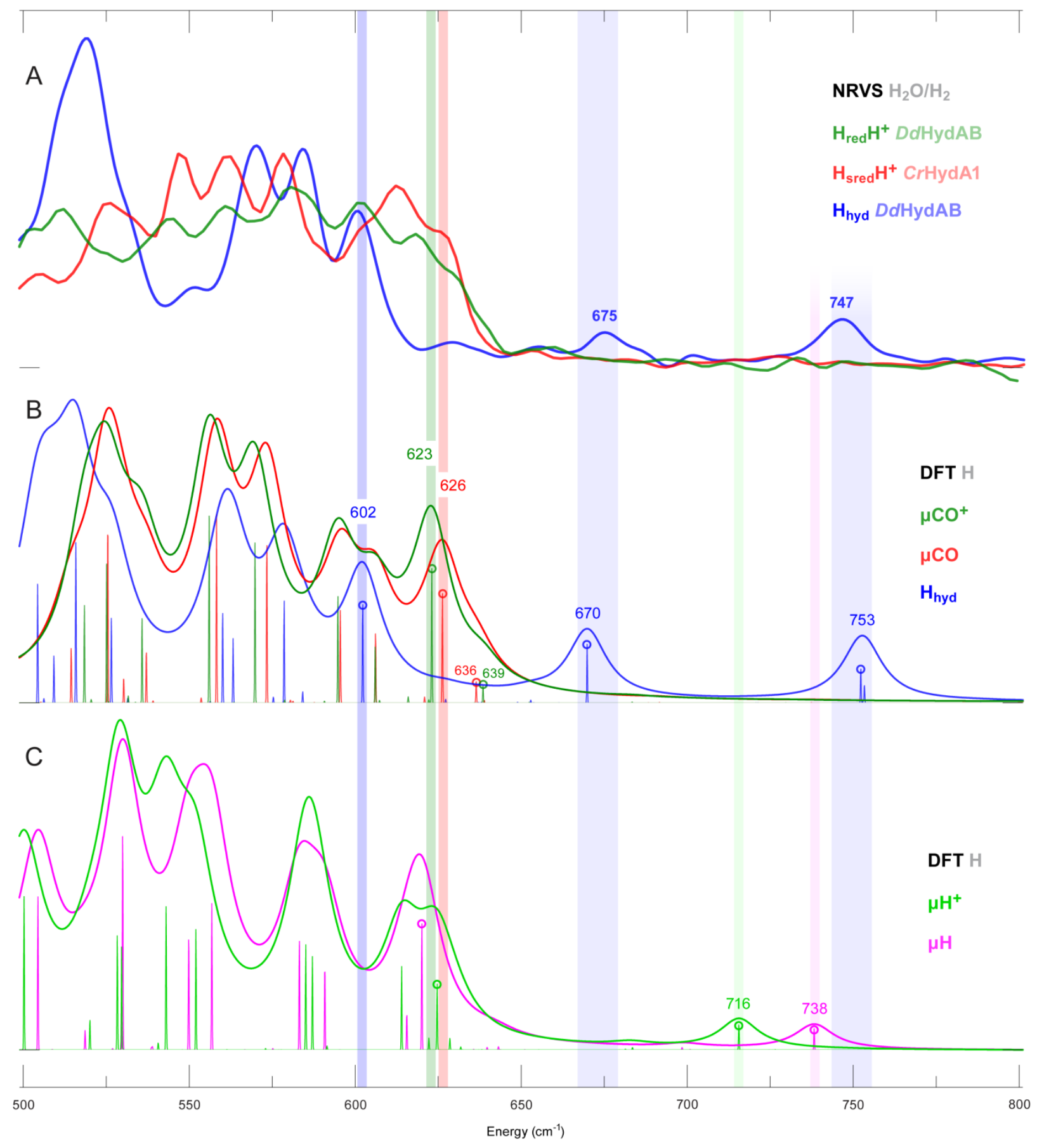

Figure S25 | ${ }^{57} \mathrm{Fe}-\mathrm{PVDOS}$ spectra of the $\mathrm{H}_{\mathrm{red}} \mathrm{H}^{+}, \mathrm{H}_{\text {sred }} \mathrm{H}^{+}$, and $\mathrm{H}_{\text {hyd }}$ states in the $500-800 \mathrm{~cm}^{-1}$ range from (A) NRVS experiments, (B) representative DFT models $\mu \mathrm{CO}^{+} / \mu \mathrm{CO} / \mathrm{H}_{\text {hyd }}$ with the bridging CO, and (C) DFT models $\mu \mathrm{H}^{+} / \mu \mathrm{H}$ with the bridging hydride. In $\mathbf{B}$ and $\mathbf{C}$, stick-style ${ }^{57} \mathrm{Fe}-\mathrm{PVDOS}$ is additionally provided showing contributions from individual modes. $\mathrm{Fe}-\mathrm{H}(-\mathrm{Fe})$ $\left(>650 \mathrm{~cm}^{-1}\right)$ and NRVS-relevant high-end Fe-CO $\left(600-630 \mathrm{~cm}^{-1}\right)$ bands/modes are labeled with their positions $\left(\mathrm{cm}^{-1}\right)$ and highlighted using vertical bars. For the modes with their sticks marked with circles, animations are available as part of the Supporting Information. The NRVS-observed (A) $\mathrm{H}_{\text {red }} \mathrm{H}^{+}$and $\mathrm{H}_{\text {sred }} \mathrm{H}^{+}$data are from this work, and the $\mathrm{H}_{\text {hyd }}$ data is from a previous report. ${ }^{1}$ 


\section{Supplementary Tables}

Table S1 | Temperature dependent peak positions and line widths of IR spectra of the $\mathrm{H}_{\text {sred }} \mathrm{H}^{+}$ state from $C r \mathrm{HydA} 1$ and the $\mathrm{H}_{\mathrm{red}} \mathrm{H}^{+}$state from $D d \mathrm{HydAB}$.

\begin{tabular}{|c|c|c|c|c|c|}
\hline \multirow{3}{*}{$\begin{array}{c}\text { Temperature } \\
(\mathrm{K})\end{array}$} & \multicolumn{5}{|c|}{ CrHydA1 Hred $_{\text {sr }}{ }^{+}$peak position / FWHM $\left(\mathrm{cm}^{-1}\right)$} \\
\hline & \multicolumn{3}{|c|}{$\mathrm{Fed}_{-}$} & \multicolumn{2}{|c|}{$\mathbf{F e}_{\mathbf{p}}-$} \\
\hline & $-\mathbf{C O}_{\mu}$ & $-\mathrm{CO}_{\mathrm{d}}$ & $-\mathbf{C N}_{\mathbf{d}}$ & $-\mathrm{CO}_{\mathrm{p}}$ & $-\mathbf{C N}_{\mathbf{p}}$ \\
\hline 280 & $-1-$ & $1883 / 6$ & $2026 / 5$ & $1919 / 8$ & $2070 / 8$ \\
\hline 200 & $1803 / 14$ & $1882 / 6$ & $2026 / 5$ & $1920 / 6$ & $2071 / 7$ \\
\hline 120 & $1801 / 11$ & $1882 / 5$ & $2026 / 5$ & $1922 / 6$ & $2072 / 7$ \\
\hline 40 & $1799 / 9$ & $1881 / 5$ & $2026 / 5$ & $1922 / 6$ & $2073 / 7$ \\
\hline
\end{tabular}

\begin{tabular}{cccccc}
\hline \multirow{2}{*}{$\begin{array}{c}\text { Temperature } \\
(K)\end{array}$} & \multicolumn{5}{c}{ DdHydA1 $\mathbf{H}_{\text {red }} \mathbf{H}^{+}$peak position $/ \mathbf{F W H M ~}\left(\mathbf{c m}^{-1}\right)$} \\
\cline { 2 - 5 } & $-\mathbf{C O}_{\boldsymbol{\mu}}$ & $-\mathbf{C O}_{\mathbf{d}}$ & $-\mathbf{C N}_{\mathbf{d}}$ & $-\mathbf{C O}_{\mathbf{p}}$ & $-\mathbf{C N}_{\mathbf{p}}$ \\
\cline { 2 - 5 } & $-/-$ & $1894 / 5$ & $2041 / 5$ & $1916 / 7$ & $2079 / 6$ \\
\hline $\mathbf{2 8 0}$ & $1810 / 7$ & $1894 / 5$ & $2040 / 5$ & $1915 / 6$ & $2080 / 6$ \\
\hline $\mathbf{2 0 0}$ & $1811 / 6$ & $1894 / 4$ & $2040 / 5$ & $1916 / 5$ & $2081 / 6$ \\
\hline $\mathbf{1 2 0}$ & $1811 / 6$ & $1894 / 4$ & $2040 / 5$ & $1916 / 4$ & $2082 / 6$ \\
\hline $\mathbf{4 0}$ & &
\end{tabular}

Peak positions and line widths were determined from each of the features assigned to the $\mathrm{H}_{\text {sred }} \mathrm{H}^{+}$state in $\mathrm{CrHydA1}$ (Figure 2 in the main text) and the $\mathrm{H}_{\mathrm{red}} \mathrm{H}^{+}$state in $D d \mathrm{HydAB}$ (Figure 3 in the main text). FWHM = full width at half maximum. 
Table S2 | Metal-ligand $\mathrm{Fe}_{\mathrm{d} / \mathrm{p}}-\mathrm{C} / \mathrm{H}$ internuclear distances in alternative model states from the present DFT structural optimization. ${ }^{[a]}$

\begin{tabular}{|c|c|c|c|c|c|c|c|}
\hline \multirow{3}{*}{$\begin{array}{l}\text { DFT } \\
\text { Model }\end{array}$} & \multicolumn{7}{|c|}{$\mathbf{F e}_{\mathrm{d} / \mathrm{p}}-\mathrm{C} / \mathrm{H}$ Internuclear Distance $(\AA)$} \\
\hline & \multicolumn{4}{|c|}{$\mathbf{F e}_{d}-$} & \multicolumn{3}{|c|}{$\mathbf{F e}_{\mathbf{p}}-$} \\
\hline & $-\mathrm{CO}_{\mu} / \mathrm{H}_{\mu}$ & $-\mathrm{CO}_{\mathrm{d}} * / \mathrm{H}_{\mathrm{d}} *$ & $-\mathrm{CO}_{\mathrm{d}}$ & $-\mathbf{C N}_{\mathbf{d}}$ & $-\mathrm{CO}_{\mu} / \mathrm{H}_{\mu}$ & $-\mathrm{CO}_{\mathrm{p}}$ & $-\mathbf{C N}_{\mathrm{p}}$ \\
\hline$\mu \mathrm{CO}^{+}$ & $1.760 /-$ & $-1-$ & 1.715 & 1.846 & $2.222 /-$ & 1.740 & 1.884 \\
\hline$\mu \mathrm{CO}$ & $1.762 /-$ & $-1-$ & 1.714 & 1.848 & $2.199 /-$ & 1.740 & 1.886 \\
\hline Hhyd & $1.898 /-$ & $-/ 1.498$ & 1.738 & 1.867 & $2.036 /-$ & 1.761 & 1.894 \\
\hline $\boldsymbol{\mu} \mathbf{H}^{+}$ & $-/ 1.669$ & $1.747 /-$ & 1.765 & 1.891 & $-/ 1.644$ & 1.736 & 1.890 \\
\hline$\mu \mathbf{H}$ & $-/ 1.672$ & $1.746 /-$ & 1.759 & 1.907 & $-/ 1.656$ & 1.737 & 1.897 \\
\hline
\end{tabular}

[a] All the $\mathrm{Fe}_{\mathrm{d} / \mathrm{p}}-\mathrm{C} / \mathrm{H}$ interatomic contacts satisfying $\mathrm{Fe} / \mathrm{p}-\mathrm{C}<3.0 \AA$ and $\mathrm{Fe} / \mathrm{p}-\mathrm{H}<2.0 \AA$ were tabulated. The values are distributed in two column blocks based on the $\mathrm{Fe}_{\mathrm{d} / \mathrm{p}}$ site identity, and on the ligand position with regard to the $[2 \mathrm{Fe}]_{\mathrm{H}}$ subcluster topology. The state-specific unoccupied ligand positions are denoted as “-“. The Fed/p-H (ironhydride) distances are given in italics. The subscript ligand labels imply either bridging ( $\mu$ ) or terminal basal (d/p) coordination at either $\mathrm{Fe}_{\mathrm{d} / \mathrm{p}}$. The terminal apical coordination at $\mathrm{Fe}_{d}$ (such as the hydride in the $\mathrm{H}_{\mathrm{hyd}}$ state) is additionally marked with an asterisk $\left(\mathrm{d}^{*}\right)$. These labels follow those used in Figures 4, S14, and S15.

Table S3 | Formal description and relative energies of alternative DFT model states.

\begin{tabular}{|c|c|c|}
\hline DFT Model & Formula ${ }^{[a]}$ & $\begin{array}{c}\text { Relative Electronic / Free } \\
\text { Energy (kcal/mol) }{ }^{[b]}\end{array}$ \\
\hline$\mu \mathrm{CO}^{+}$ & {$[4 \mathrm{Fe}-4 \mathrm{~S}]_{\mathrm{H}^{2+}} \mathrm{Fe}_{\mathrm{p}}(\mathrm{I}) \mathrm{Fe}_{\mathrm{d}}(\mathrm{I}) \quad\left[\mathrm{NH}_{2}{ }^{+}\right] \quad\left[\mathrm{CO}_{\mu}\right]$} & $\equiv 0.0 / 0.0$ \\
\hline $\boldsymbol{\mu} \mathbf{H}^{+}$ & {$\left[4 \mathrm{Fe}-4 \mathrm{~S}_{\mathrm{H}^{2+}} \mathrm{Fe}_{\mathrm{p}}(\mathrm{II}) \mathrm{Fe}_{\mathrm{d}}(\mathrm{II}) \quad[\mathrm{NH}] \quad\left[\mathrm{CO}_{\mathrm{d}} *\right] \quad\left[\mathrm{H}_{\mu}^{-}\right]\right.$} & $-28.4 /-26.6$ \\
\hline$\mu \mathrm{CO}$ & {$\left[\begin{array}{lllll}4 \mathrm{Fe}-4 \mathrm{~S} & \mathrm{H}^{+} & \mathrm{Fe}_{\mathrm{p}}(\mathrm{I}) \mathrm{Fe}_{\mathrm{d}}(\mathrm{I}) & {\left[\mathrm{NH}_{2}{ }^{+}\right]} & {\left[\mathrm{CO}_{\mu}\right]}\end{array}\right.$} & $\equiv 0.0 / 0.0$ \\
\hline Hhyd & {$\left[4 \mathrm{Fe}-4 \mathrm{~S}_{\mathrm{H}^{+}} \mathrm{Fe}_{\mathrm{p}}(\mathrm{II}) \mathrm{Fe}_{\mathrm{d}}(\mathrm{II}) \quad[\mathrm{NH}] \quad\left[\mathrm{CO}_{\mu}\right] \quad\left[\mathrm{H}_{\mathrm{d}}{ }^{*-}\right]\right.$} & $-11.9 /-12.2$ \\
\hline$\mu \mathbf{H}$ & {$[4 \mathrm{Fe}-4 \mathrm{~S}]_{\mathrm{H}^{+}} \mathrm{Fe}_{\mathrm{p}}(\mathrm{II}) \mathrm{Fe}_{\mathrm{d}}(\mathrm{II}) \quad[\mathrm{NH}]$} & $-32.1 /-30.8$ \\
\hline
\end{tabular}

[a] Short-hand formula for the $\mathrm{H}_{\mathrm{hyd}}$ alternatives describes oxidation levels of the $(i)[4 \mathrm{Fe}-4 \mathrm{~S}]_{\mathrm{H}}$ and $(i i)[2 \mathrm{Fe}]_{\mathrm{H}}$ subclusters, (iii) ADT bridgehead nitrogen protonation status, and (iv) either Fe F-to-Fe $_{\mathrm{p}}$ (semi)bridging (subscript code $\mu$ ) or Fed terminal apical (subscript code $\mathrm{d}^{*}$ ) positions of the special CO ligand, as well as ( $v$ ) iron hydride state when the latter is present. The labels follow those used in Figures 4, S14, and S15. The listed [4Fe-4S $]_{\mathrm{H}}$ and $[2 \mathrm{Fe}]_{\mathrm{H}}$ oxidation levels were confirmed by analysis of charge/spin electron densities from the present DFT solutions, see additionally Table S5. For the schematic representation, see Figure 1 of the main text.

[b] The relative electronic-only enthalpies / Gibbs free energies are compared separately in two internally isoelectronic / isomeric model sets, $\left[\mu \mathrm{CO}^{+}, \mu \mathrm{H}^{+}\right]$and $\left[\mu \mathrm{CO}, \mathrm{H}_{\mathrm{hyd}}, \mu \mathrm{H}\right]$. 
Table S4 | Experimental and calculated IR band frequencies of the $\mathrm{H}_{\mathrm{red}} \mathrm{H}^{+}$and $\mathrm{H}_{\text {sred }} \mathrm{H}^{+}$states and their assignment to the $\mathrm{CO} / \mathrm{CN}^{-}$ligands on the proximal and distal $\mathrm{Fe}$ sites. ${ }^{[a]}$

\begin{tabular}{|c|c|c|c|c|c|c|}
\hline Sample (Exp) / Model (DFT) & $\mathrm{CO}_{\mu}$ & $\mathrm{CO}_{\mathrm{d}}$ & $\mathrm{CO}^{*} *$ & $\mathrm{CO}_{\mathrm{p}}$ & $\mathbf{C N}_{\mathbf{d}}$ & $\mathbf{C N}_{\mathrm{p}}$ \\
\hline $\operatorname{Exp} \mathbf{H}_{\text {red }} \mathbf{H}^{+}$ & 1810 & 1894 & - & 1916 & 2041 & 2079 \\
\hline DFT $\mu \mathrm{CO}^{+}$ & 1822 & 1879 & - & 1940 & 2007 & 2092 \\
\hline DFT $\mu \mathbf{H}^{+}$ & - & 2003 & 1940 & 1926 & 2074 & 2085 \\
\hline Exp $\mathbf{H}_{\text {sred }} \mathbf{H}^{+}$ & 1803 & 1882 & - & 1919 & 2026 & 2070 \\
\hline DFT $\mu \mathrm{CO}$ & 1801 & 1871 & - & 1940 & 2009 & 2077 \\
\hline DFT $\mu \mathrm{H}$ & - & 1996 & $1929^{[\mathbf{b}]}$ & $1929^{[\mathbf{b}]}$ & $2088^{[\mathrm{c}]}$ & $2073^{[\mathbf{c}]}$ \\
\hline
\end{tabular}

[a] The $\mathrm{CO} / \mathrm{CN}$ ligand labels follow those used in Figures 4, S14, and S15. Animations illustrating the calculated $\mathrm{CO} / \mathrm{CN}$ modes are available in Supporting Information separately.

[b] The two strongly coupled vibrational modes calculated at 1934 and $1929 \mathrm{~cm}^{-1}$ which reduce to a single band at $1929 \mathrm{~cm}^{-1}$ upon broadening. Other minor couplings were omitted in this table.

[c] Note the reversed order of these frequencies with respect to those from the $\mu \mathrm{H}^{+}$model.

Table S5 | $<[2 \mathrm{Fe}]_{\mathrm{H}}>,<[4 \mathrm{Fe}-4 \mathrm{~S}]_{\mathrm{H}}>$, and $<$ Protein $>$ molecular fragments charge and spin populations in DFT alternative model states.

\begin{tabular}{|c|c|c|c|}
\hline \multirow{2}{*}{ DFT Model } & \multicolumn{3}{|c|}{ Fragment Charge | Spin $\left(\mathrm{e}^{-}\right)^{[\mathrm{a}]}$} \\
\hline & $<[2 \mathrm{Fe}]_{\mathrm{H}}>[\mathrm{b}]$ & $\left\langle[4 \mathrm{Fe}-4 \mathrm{~S}]_{\mathrm{H}}>[\mathrm{c}]\right.$ & $<$ Protein $>[d]$ \\
\hline$<$ Prototype $^{+}>[\mathrm{e}]$ & $-1 \mid 0$ & $-2 \mid 0$ & $+1 \mid 0$ \\
\hline$\mu \mathrm{CO}^{+}$ & \begin{tabular}{l|l|}
$-1.24 \mid 0.00$
\end{tabular} & \begin{tabular}{l|l|}
$-1.40 \mid 0.00$
\end{tabular} & \begin{tabular}{l|l}
+0.64 & 0.00
\end{tabular} \\
\hline$\mu \mathbf{H}^{+}$ & $-1.34 \mid 0.00$ & $-1.33 \mid 0.00$ & $+0.67 \mid 0.00$ \\
\hline <Prototype $>[\mathrm{e}]$ & \begin{tabular}{l|l}
$-1 \mid 0$ \\
\end{tabular} & \begin{tabular}{l|l}
-3 & 1
\end{tabular} & \begin{tabular}{l|l}
+1 & 0
\end{tabular} \\
\hline$\mu \mathrm{CO}$ & $-1.32 \mid-0.01$ & $-2.32 \mid 1.01$ & $+0.65 \mid 0.00$ \\
\hline $\mathbf{H}_{\text {hyd }}$ & $-1.37 \mid-0.01$ & \begin{tabular}{l|l}
-2.19 & 1.01
\end{tabular} & $+0.56 \mid 0.00$ \\
\hline$\mu \mathbf{H}$ & \begin{tabular}{l|l}
$-1.44 \mid$ & 0.00
\end{tabular} & \begin{tabular}{l|l}
-2.17 & 1.00
\end{tabular} & \begin{tabular}{l|l}
+0.62 & 0.00
\end{tabular} \\
\hline
\end{tabular}

[a] Fragment values are cumulative atomic Mulliken populations; the spin populations are given in unpaired electrons.

$[\mathbf{b}]<[2 \mathrm{Fe}]_{\mathrm{H}}>$ fragment represents the $[2 \mathrm{Fe}]_{\mathrm{H}}$ subscluster, or the $\mathrm{Fe}_{\mathrm{p}}$ and $\mathrm{Fe}_{\mathrm{d}}$ sites including their inorganic ligands.

[c] $\left\langle[4 \mathrm{Fe}-4 \mathrm{~S}]_{\mathrm{H}}>\right.$ fragment represents the $[4 \mathrm{Fe}]_{\mathrm{H}}$ subcluster including the four Fe-bound cysteines $\mathrm{C} 170, \mathrm{C} 225, \mathrm{C} 417$, and $\mathrm{C} 421$ ( $C r$ HydA1 sequence).

[d] <Protein> fragment represents the $2^{\text {nd }}$-shell protein ligands to the H-cluster, specifically residues P93, A94, C169, P194, Q195, M223, P224, K228, and M415 (CrHydA1 sequence) of the DFT model as shown in the figures; the total $+1<$ Protein> prototype fragment charge is due to the positively charged side chain of K228.

[e] Formal prototype charge $\mid$ spin fragment populations at the two $[4 \mathrm{Fe}-4 \mathrm{~S}]_{\mathrm{H}^{2+}}$ (top rows) and $[4 \mathrm{Fe}-4 \mathrm{~S}]_{\mathrm{H}^{1+}}$ (bottom rows) oxidation levels that follow Figure 1 and Table S3. 


\section{Supplementary Discussion}

\section{What's in a name: [FeFe] hydrogenase $\mathrm{H}$-cluster state nomenclature}

An often confusing aspect of the $[\mathrm{FeFe}]$ hydrogenase literature is the current diversity in nomenclature used to refer to the various states of the active site $\mathrm{H}$-cluster, most often associated with IR spectral features. To our knowledge, all groups agree that $\mathrm{H}_{\mathrm{ox}}$ is a state in which the $[4 \mathrm{Fe}-4 \mathrm{~S}]_{\mathrm{H}}$ subcluster is oxidized and the $[2 \mathrm{Fe}]_{\mathrm{H}}$ subcluster is mixed valent ( $\mathrm{Fe}(\mathrm{II}) \mathrm{Fe}(\mathrm{I})$ ). This state is typically observed under mildly oxidizing conditions in the absence of $\mathrm{H}_{2}$ and gives rise to IR bands at approximately 2093, 2079, 1965, 1940 and $1802 \mathrm{~cm}^{-1}{ }^{2}$ and a rhombic EPR spectrum with $\mathrm{g} \approx 2.11,2.05$ and $2.00 .{ }^{3}$ One-electron reduction of the H-cluster gives the EPR silent $\mathrm{H}_{\text {red }}$ state. ${ }^{4}$ Prior to $2016, \mathrm{H}_{\text {red }}$ simply referred to a one-electron reduced state, where the protonation state was not considered, but where the reducing equivalent was thought to be localized on $[2 \mathrm{Fe}] \mathrm{H}^{5}{ }^{5-6}$ In at least one publication ${ }^{7}$ this state was simply called red. Later, through photoexcitation experiments ${ }^{8}$ and $\mathrm{pH}$-dependent redox titrations ${ }^{9}$ the $\mathrm{H}_{\text {red }}$ state was shown to be a mixture of two one-electron reduced states, one in which $[4 \mathrm{Fe}-4 \mathrm{~S}] \mathrm{H}$ was reduced (state 1 ), with a dominant IR band at $1932 \mathrm{~cm}^{-1}$, and the other in which [2Fe] $\mathrm{H}$ was reduced and protonated at the bridgehead amine of the ADT ligand (state 2), with a dominant IR band at $1891 \mathrm{~cm}^{-1}$. Katz and co-workers ${ }^{8}$ named state 1 the $\mathrm{H}_{\text {red' }}$ state and state 2 the $\mathrm{H}_{\text {red }}$ state, while we named state 1 the $\mathrm{H}_{\text {red }}$ state and state 2 the $\mathrm{H}_{\mathrm{red}} \mathrm{H}^{+}$state. Subsequently, Stripp and Haumann have suggested that state 1 has a protonated $[4 \mathrm{Fe}-4 \mathrm{~S}] \mathrm{H}$ subcluster ${ }^{10-13}$ and that state 2 contains a hydride bridging the two $\mathrm{Fe}$ ions of $[2 \mathrm{Fe}] \mathrm{H}^{10-11,14}$. The notion of a bridging hydride in the $\mathrm{H}$-cluster originated from site-selective X-ray absorption and emission spectroscopy on a state referred to as sred, ${ }^{7}$ which was generated by reducing $\mathrm{CrHydA} 1$ with either $\mathrm{H}_{2}$ or sodium dithionite at $\mathrm{pH} 8$. The conditions typically yield the two-electron reduced state, which we refer to as the $\mathrm{H}_{\mathrm{red}} \mathrm{H}^{+}$state. ${ }^{9}$ In this state, $[2 \mathrm{Fe}]_{\mathrm{H}}$ is thought to be in a homovalent $\mathrm{Fe}(\mathrm{I}) \mathrm{Fe}(\mathrm{I})$ state and $[4 \mathrm{Fe}-4 \mathrm{~S}]_{\mathrm{H}}$ is reduced to the $1+$ state. This gives rise to an IR spectrum with a dominant feature at $1882 \mathrm{~cm}^{-1}$ and an EPR spectrum reminiscent of reduced [4Fe-4S] clusters. ${ }^{6,15}$ More recently, the Haumann group has started referring to their sred state as the Hsred state. ${ }^{16}$ The results in this publication exclude that bridging hydrides exist in the well-characterized states referred to as $\mathrm{H}_{\text {red }} \mathrm{H}^{+}$(a.k.a. Hred or red) and $\mathrm{H}_{\text {sred }} \mathrm{H}^{+}$(a.k.a. Hsred or sred). We cannot rule out that Haumann and co-workers have stabilized alternative states so far not characterized by IR spectroscopy, and that these states contain bridging hydrides. However, considering that the conditions used in our work and in the work from Haumann and co-workers in order to generate the $\mathrm{H}_{\text {red }} \mathrm{H}^{+}$and $\mathrm{H}_{\text {sred }} \mathrm{H}^{+}$state are similar (reduction with $\mathrm{H}_{2}$ or sodium dithionite at $\mathrm{pH} 8$ ), this possibility seems unlikely. Furthermore, Haumann and co-workers contend that the IR spectra from the $\mathrm{H}_{\mathrm{red}} \mathrm{H}^{+}$and $\mathrm{H}_{\text {sred }} \mathrm{H}^{+}$states indicate bridging hydride bound states. ${ }^{14}$ In this respect, our work disagrees with this interpretation entirely. 


\section{Extended details on the DFT results and modeling}

Method and Models. The PBE0 ${ }^{17-18}$ hybrid functional has been employed in this work at its higher computational cost, than the $\mathrm{BP} 86^{19-20}$ functional applied previously by some of us to model the $\mathrm{H}_{\text {hyd }}$ state. ${ }^{1}$ 21-22 Benefits of the PBE0 application are, as presently found, $(i)$ proper modeling of the redox balance between the $[4 \mathrm{Fe}-4 \mathrm{~S}]_{\mathrm{H}}$ and $[2 \mathrm{Fe}]_{\mathrm{H}}$ subclusters at the two redox levels (Table S3 and S5), together with (ii) respectable quality results from the normal mode analysis. Notably, the models $\mu \mathrm{CO}$ and $\mu \mathrm{CO}^{+}$produced vanishingly small spin populations at the two $[2 \mathrm{Fe}]_{\mathrm{H}} \mathrm{Fe}(\mathrm{I})$ sites (rather than a broken-symmetry state with antiferromagnetic character), indicating the $\mathrm{Fe}(\mathrm{I})-\mathrm{Fe}(\mathrm{I})$ metal-metal bonding as depicted in Figure 1B. In summary, PBE0 provided an empirically better overall match between the NRVS-observed and DFT-calculated ${ }^{57} \mathrm{Fe}-\mathrm{PVDOS}$ spectra through the entire measured range $\left(0-800 \mathrm{~cm}^{-1}\right)$ when using the entire $\mathrm{H}$ cluster model $\left(L^{\prime}\right)$; in contrast, BP86 was aimed by us earlier ${ }^{1,21-22}$ to the Fe-H hydride bands of $\mathrm{H}_{\text {hyd }}$ in the $600-800 \mathrm{~cm}^{-1}$ range only when using a model excluding the $[4 \mathrm{Fe}-4 \mathrm{~S}]_{\mathrm{H}}$ subcluster $(L)$. As shown in Figures S20A-C and S25A-B, the present PBE0-based methodology seamlessly reproduces NRVS spectra of $\mathrm{H}_{\text {red }} \mathrm{H}^{+}$and $\mathrm{H}_{\text {sred }} \mathrm{H}^{+}$, as well as that of $\mathrm{H}_{\text {hyd. }}$.

$\mathrm{H}_{\text {red }} \mathrm{H}^{+}$and $\mathrm{H}_{\text {sred }} \mathrm{H}^{+}$vs $\mathrm{H}_{\text {hyd: }}{ }^{57} \mathrm{Fe}-\mathrm{PVDOS}$. A point of transition between the high-intensity and the low-intensity or baseline (at higher vibrational energies) regions in NRVS spectra is known to aid in comparative analysis of related molecular systems. As an example, high-end of the Fe-S band region $\left(360-400 \mathrm{~cm}^{-1}\right.$ ) across the ${ }^{57} \mathrm{Fe}$-enriched $[3 \mathrm{Fe}-4 \mathrm{~S}]^{1+/ 0}$ and $[4 \mathrm{Fe}-4 \mathrm{~S}]^{2+/ 1+}$ cluster variants in the $P f \mathrm{Fd}$ D14C protein has been correlated with average oxidation level of iron sites in these iron-sulfur clusters. ${ }^{23}$ Extending this approach to [FeFe] hydrogenase, high-end of the $\mathrm{Fe}-\mathrm{CO} / \mathrm{CN}$ region $\left(600-640 \mathrm{~cm}^{-1}\right)$ in the $[2 \mathrm{Fe}]_{\mathrm{H}}$ subcluster can serve its ${ }^{57} \mathrm{Fe}-\mathrm{NRVS}$ diagnostic purpose. We found that the high-end $\mathrm{Fe}-\mathrm{CO} / \mathrm{CN}$ vibrational energy is at $\sim 610 \mathrm{~cm}^{-1}$ for $\mathrm{Hhyd}$, while it is at $\sim 620-640 \mathrm{~cm}^{-1}$ for $\mathrm{H}_{\mathrm{red}} \mathrm{H}^{+} / \mathrm{H}_{\text {sred }} \mathrm{H}^{+}$; the absolute position of the bands and their $\sim 20-30 \mathrm{~cm}^{-}$ 1 shifts are consistent here between the observed (Figure S25A) and calculated (Figure S25B)

${ }^{57} \mathrm{Fe}-\mathrm{PVDOS}$ spectra. Our analysis reveals that in the $\mu \mathrm{CO}^{+} / \mu \mathrm{CO}$ (as well as $\mu \mathrm{H}^{+} / \mu \mathrm{H}$ ) DFT models of $\mathrm{H}_{\text {red }} \mathrm{H}^{+} / \mathrm{H}_{\text {sred }} \mathrm{H}^{+}$, the high-end $\mathrm{Fe}-\mathrm{CO} / \mathrm{CN}$ modes are coupled to the ADT fragment motion, while no such coupling is present in the $\mathrm{H}_{\text {hyd }}$ model; see the normal mode animations available as part of the Supporting Information. The representative models $\mu \mathrm{CO}^{+} / \mu \mathrm{CO}$ for the $\mathrm{H}_{\mathrm{red}} \mathrm{H}^{+} / \mathrm{H}_{\text {sred }} \mathrm{H}^{+}$states display ADT vibrations at $639 / 636 \mathrm{~cm}^{-1}$ ( $\mathrm{S}-\mathrm{C}$ stretches coupled to the $\mathrm{NH}_{2}{ }^{+}$- bridgehead bends) which supply only minor ${ }^{57} \mathrm{Fe}-\mathrm{PVDOS}$ intensity and appear as highend shoulders of the Fe-CO/CN bands, as shown in Figure S25B. 


\section{Supplementary References}

1. Pelmenschikov, V.; Birrell, J. A.; Pham, C. C.; Mishra, N.; Wang, H.; Sommer, C.; Reijerse, E.; Richers, C. P.; Tamasaku, K.; Yoda, Y.; Rauchfuss, T. B.; Lubitz, W.; Cramer, S. P., Reaction coordinate leading to $\mathrm{H}_{2}$ production in [FeFe]hydrogenase identified by nuclear resonance vibrational spectroscopy and density functional theory. J. Am. Chem. Soc. 2017, 139 (46), 16894-16902.

2. De Lacey, A. L.; Stadler, C.; Cavazza, C.; Hatchikian, E. C.; Fernandez, V. M., FTIR characterization of the active Site of the Fe-hydrogenase from Desulfovibrio desulfuricans. J. Am. Chem. Soc. 2000, 122(45), 11232-11233.

3. Hagen, W. R.; van Berkel-Arts, A.; Kruse-Wolters, K. M.; Dunham, W. R.; Veeger, C., EPR of a novel high-spin component in activated hydrogenase from Desulfovibrio vulgaris (Hildenborough). FEBS Lett. 1986, 201 (1), 158-162.

4. Adams, M. W. W., The structure and mechanism of iron-hydrogenases. Biochim. Biophys. Acta 1990, 1020 (2), 115-145.

5. Roseboom, W.; De Lacey, A. L.; Fernandez, V. M.; Hatchikian, E. C.; Albracht, S. P., The active site of the [FeFe]hydrogenase from Desulfovibrio desulfuricans. II. Redox properties, light sensitivity and CO-ligand exchange as observed by infrared spectroscopy. J. Biol. Inorg. Chem. 2006, 11(1) 102-118.

6. Silakov, A.; Kamp, C.; Reijerse, E.; Happe, T.; Lubitz, W., Spectroelectrochemical characterization of the active site of the [FeFe] hydrogenase HydA1 from Chlamydomonas reinhardtii. Biochemistry 2009, 48 (33), 7780-7786.

7. Chernev, P.; Lambertz, C.; Brunje, A.; Leidel, N.; Sigfridsson, K. G.; Kositzki, R.; Hsieh, C. H.; Yao, S.; Schiwon, R.; Driess, M.; Limberg, C.; Happe, T.; Haumann, M., Hydride binding to the active site of [FeFe]-hydrogenase. Inorg.Chem. 2014, 53 (22), 12164-12177.

8. Katz, S.; Noth, J.; Horch, M.; Shafaat, H. S.; Happe, T.; Hildebrandt, P.; Zebger, I., Vibrational spectroscopy reveals the initial steps of biological hydrogen evolution. Chem. Sci. 2016, 7 (11), 6746-6752.

9. Sommer, C.; Adamska-Venkatesh, A.; Pawlak, K.; Birrell, J. A.; Rüdiger, O.; Reijerse, E. J.; Lubitz, W., Proton coupled electronic rearrangement within the H-cluster as an essential step in the catalytic cycle of [FeFe] hydrogenases. J. Am. Chem. Soc. 2017, 139(4), 1440-1443.

10. Haumann, M.; Stripp, S. T., The molecular proceedings of biological hydrogen turnover. Acc. Chem. Res. 2018, 51 (8), $1755-1763$.

11. Mebs, S.; Duan, J.; Wittkamp, F.; Stripp, S. T.; Happe, T.; Apfel, U. P.; Winkler, M.; Haumann, M., Differential protonation at the catalytic six-iron cofactor of [FeFe]-hydrogenases revealed by ${ }^{57} \mathrm{Fe}$ nuclear resonance X-ray scattering and quantum mechanics/molecular mechanics analyses. Inorg. Chem. 2019, 58 (6), 4000-4013.

12. Senger, M.; Laun, K.; Wittkamp, F.; Duan, J.; Haumann, M.; Happe, T.; Winkler, M.; Apfel, U. P.; Stripp, S. T., Protoncoupled reduction of the catalytic $[4 \mathrm{Fe}-4 \mathrm{~S}]$ cluster in $[\mathrm{FeFe}]$-hydrogenases. Angew. Chem. Int. Ed. Engl. 2017, 56 (52), 16503-16506.

13. Senger, M.; Mebs, S.; Duan, J.; Shulenina, O.; Laun, K.; Kertess, L.; Wittkamp, F.; Apfel, U. P.; Happe, T.; Winkler, M.; Haumann, M.; Stripp, S. T., Protonation/reduction dynamics at the [4Fe-4S] cluster of the hydrogen-forming cofactor in [FeFe]-hydrogenases. Phys. Chem. Chem. Phys. 2018, 20 (5), 3128-3140.

14. Mebs, S.; Senger, M.; Duan, J.; Wittkamp, F.; Apfel, U. P.; Happe, T.; Winkler, M.; Stripp, S. T.; Haumann, M., Bridging hydride at reduced $\mathrm{H}$-cluster species in [FeFe]-hydrogenases revealed by infrared spectroscopy, isotope editing, and quantum chemistry. J. Am. Chem. Soc. 2017, 139 (35), 12157-12160.

15. Adamska, A.; Silakov, A.; Lambertz, C.; Rüdiger, O.; Happe, T.; Reijerse, E.; Lubitz, W., Identification and characterization of the "super-reduced" state of the H-cluster in [FeFe] hydrogenase: a new building block for the catalytic cycle? Angew. Chem. Int. Ed. Engl. 2012, 51 (46), 11458-11462.

16. Winkler, M.; Senger, M.; Duan, J.; Esselborn, J.; Wittkamp, F.; Hofmann, E.; Apfel, U. P.; Stripp, S. T.; Happe, T., Accumulating the hydride state in the catalytic cycle of [FeFe]-hydrogenases. Nat. Commun. 2017, 8, 16115.

17. Adamo, C.; Barone, V., Toward reliable density functional methods without adjustable parameters: The PBE0 model. $J$. Chem. Phys. 1999, 110 (13), 6158-6170.

18. Perdew, J. P.; Burke, K.; Ernzerhof, M., Generalized gradient approximation made simple. Phys. Rev. Lett. 1996, 77 (18), 3865-3868.

19. Perdew, J. P., Density-functional approximation for the correlation energy of the inhomogeneous electron gas. Phys. Rev. B 1986, 33 (12), 8822-8824.

20. Becke, A. D., Density-functional exchange-energy approximation with correct asymptotic behavior. Phys. Rev. A 1988, 38 (6), 3098-3100.

21. Pham, C. C.; Mulder, D. W.; Pelmenschikov, V.; King, P. W.; Ratzloff, M. W.; Wang, H.; Mishra, N.; Alp, E. E.; Zhao, J.; Hu, M. Y.; Tamasaku, K.; Yoda, Y.; Cramer, S. P., Terminal hydride species in [FeFe]-hydrogenases are vibrationally coupled to the active site environment. Angew. Chem. Int. Ed. Engl. 2018, 57 (33), 10605-10609.

22. Reijerse, E. J.; Pham, C. C.; Pelmenschikov, V.; Gilbert-Wilson, R.; Adamska-Venkatesh, A.; Siebel, J. F.; Gee, L. B.; Yoda, Y.; Tamasaku, K.; Lubitz, W.; Rauchfuss, T. B.; Cramer, S. P., Direct observation of an iron-bound terminal hydride in [FeFe]-hydrogenase by nuclear resonance vibrational spectroscopy. J. Am. Chem. Soc. 2017, 139 (12), 4306-4309.

23. Lauterbach, L.; Gee, L. B.; Pelmenschikov, V.; Jenney, F. E.; Kamali, S.; Yoda, Y.; Adams, M. W. W.; Cramer, S. P., Characterization of the $[3 \mathrm{Fe}-4 \mathrm{~S}]^{0 / 1+}$ cluster from the D14C variant of Pyrococcus furiosus ferredoxin via combined NRVS and DFT analyses. Dalton Trans. 2016, 45 (17), 7215-7219. 